
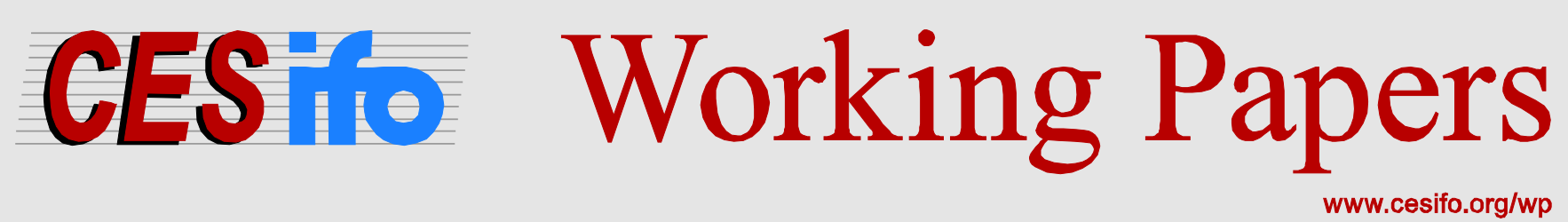

\title{
Tackling Spillovers by Taxing Corporate Income in the European Union at Source
}

\author{
Sijbren Cnossen
}

\author{
CESIFO WORKING PAPER NO. 5790 \\ CATEgORY 1: PUBLIC FinANCE \\ MARCH 2016
}

An electronic version of the paper may be downloaded

- from the SSRN website: Www.SSRN.com

- from the RePEc website: Www.RePEc.org

- from the CESifo website: www.CESifo-group.org/wp 


\title{
Tackling Spillovers by Taxing Corporate Income in the European Union at Source
}

\begin{abstract}
This paper surveys and evaluates the corporation tax (CT) systems of the Member States of the European Union on the basis of a comprehensive taxonomy of actual and potential regimes, which have as their base either profits, profits and interest, or economic rents. The current regimes give rise to various instate and interstate spillovers, which violate the basic tenets neutrality and subsidiarity - of the single market. The trade-offs between the implications of these tenets - harmonization and diversity, respectively - can be reconciled by a bottom-up, reversible strategy of strengthening source-based taxation and approximating tax rates. The strategy starts with dual income taxation, proceeds with final source withholding taxes and rate approximation, and is made complete by comprehensive business income taxation. Common base taxation, if desired, should probably be left to the Member States themselves.
\end{abstract}

JEL-Codes: H250, H320, H710, H730, H770.

Keywords: corporation tax, European Union, tax coordination, tax spillovers, dual income tax, comprehensive business income tax, allowance for corporate equity, rate of return allowance.

\author{
Sijbren Cnossen \\ CPB Netherlands Bureau for Economic Policy Analysis \\ P.O. Box 80501 \\ The Netherlands - 2508 GM The Hague \\ cnossen@ese.eur.nl
}

This version 18 February 2016

This paper is based on an earlier version presented at the 71st Annual Congress of the International Institute of Public Finance, held in Dublin, 20-23 August, 2015. I am grateful to the participants in the session on corporations taxes for their observations. I would also like to thank Johannes Hers, Bas Jacobs, Arjan Lejour, and Judith Payne for their comments on the present version of the paper,. Of course, they should not be held accountable for any remaining mistakes or incomplete analyses. 


\section{Introduction}

The single market of the European Union (EU) should enable businesses to source anywhere, manufacture anywhere and sell anywhere without being hampered by double taxation and tax discrimination issues arising under the corporation taxes (CTs) of the Member States (European Commission, 2015). At the same time, harmful tax competition between Member States, which would jeopardize revenue collections, should be avoided. With this in mind, the European Commission has made various proposals for aligning the CTs in the EU to remove tax obstacles for companies operating on an EU-wide basis. Following the publication of a number of expert reports (Neumark Committee (1962); van den Tempel (1970); Ruding Committee (1992)) and the issue of a Code of Conduct (European Commission, 1998), the European Commission (2001) proposed a Common Consolidated Corporate Tax Base (CCCTB) for European companies. The common base would subsequently be allocated to participating Member States which could then apply their own CT rate.

Neither the various reports nor the CCCTB proposal ever left the drawing board. Yet, some approximation or coordination of the CTs within the EU remains attractive, because it would reduce compliance costs for corporations established in more than one Member State, eliminate various forms of tax arbitrage, enable cross-border loss offsets and business restructuring, and reduce tax-induced distortions of the intra-EU allocation of capital. The European Commission believes that these objectives should be achieved by strengthening source based taxation of corporate income.

In examining the issues, perhaps more should be done to evaluate the need for CT coordination in the EU against the basic principles that govern the tax relationships between the Member States. The leitmotiv of the Treaty of Rome (1957) is that the single market should ensure an efficient allocation of resources. Hence, unless expressly stipulated otherwise, CT regimes should affect saving and investment decisions as little as possible. The neutrality criterion implies that the effective tax rate (CT and personal income tax (PT)) on various forms of capital income, such as retained profits, dividends and interest, should be approximately the same.

Subsequently, the Treaty of Maastricht (1992) enshrined subsidiarity as the guiding principle in the discussion on the assignment of policy functions in the EU. Subsidiarity proceeds from a presumption in favor of decentralization. ${ }^{1}$ Basically, policy functions, including taxation, should be exercised by the Member States, although the states are obliged to consider the effects of their actions on other Member States. Subsidiarity implies that concerted coordination between the Member States should be minimized.

\footnotetext{
1 The present formulation is contained in Article 5(3) of the Treaty on European Union (2012; consolidated version following the Treaty of Lisbon, which entered into force on 1 December 2009): "Under the principle of subsidiarity, in areas which do not fall within its exclusive competence, the Union shall act only if and in so far as the objectives of the proposed action cannot be sufficiently achieved by the Member States, either at central level or at regional and local level, but can rather, by reason of the scale or effects of the proposed action, be better achieved at Union level.”
} 
Tax neutrality generally requires a substantial degree of tax harmonization.

Subsidiarity, in contrast, implies that each Member State should be permitted as much tax sovereignty as is commensurate with the goals of free trade and free competition in the single internal market. In other words, tax systems should not substantially affect other Member States and should require little coordination, except perhaps on basic design principles. ${ }^{2}$ As argued below, substantial CT reform is called for to meet tax neutrality and subsidiarity.

Against this background, the following section reviews the various CT regimes that can be distinguished in the EU and the tax literature. In light of this analysis, Section 3 surveys and evaluates the actual CT regimes of the Member States and attempts to distil common features. Section 4 then elaborates on the basic principles - neutrality and subsidiarity - that should guide the tax treatment of corporations in the EU. On the basis of these principles, Section 5 sketches a roadmap for a bottom up, reversible approximation of CT regimes in the EU.

\section{Options for Taxing Corporate Source Income}

This section starts with an overview of the three main CT regimes that can be distinguished. This is followed by a more detailed discussion of the various variants that are found in the EU and the tax literature.

\subsection{Overview of CT regimes}

CTs in the EU are based on the OECD Model Convention with respect to Taxes on Income and on Capital (OECD, 2010), which drew on the blueprint agreed to by the League of Nations in the 1920s. As befits its pedigree, the original CT was largely designed for economies in which cross-border transactions were the exception rather than the rule, in which debt could be distinguished clearly from equity, and in which shareholders were natural persons generally residing in the country in which the corporation had been established. In such economies, CTs were meant to be a schedular tax on the equity income of shareholders, that is, profits. Interest was deductible in ascertaining profits and was taxed in the hands of the debt-holder.

But globalization and capital market liberalization and innovation have turned this traditional CT model on its head. Debt has become largely indistinguishable from equity through the use of financial derivatives and hybrid instruments. Unlike equity income, interest is not taxed at the corporate level and may not be taxed at all if it accrues to foreign debt-holders or exempt entities. This discrepancy in the treatment of returns that are largely identical suggests that equity income and interest should be taxed alike at the level of the corporation.

\footnotetext{
${ }^{2}$ Perhaps the value-added tax (VAT) is a good example. By agreeing on a tax-credit destination-based type of general consumption tax, Member States accomplished substantial neutrality regarding intraEU trade (border tax adjustments can be made unambiguously and expeditiously). At the same time, the administration and proceeds of the tax are left in the hands of the Member States, as well as the power to set the rates (subject to a minimum). It should be emphasized, however, that the 1977 VAT agreement puts Member States in the straight-jacket of an outmoded VAT which is not attuned to the realities of modern economies (for an early assessment, see Cnossen (2003).
} 
Equity income differs from interest, however, to the extent that it consists of a normal rate of return (in other words, the opportunity cost of an investment, comparable to interest) and an above-normal rate of return or economic rent. The normal or hurdle rate of return is required to make the corporation's marginal investment just worthwhile. The CT reduces this return and, hence, affects the level of investment and, possibly, economic growth. If this is to be avoided, the normal rate of return should not be taxed and neither should interest (to the extent that it equates the normal return). By contrast, the above-normal return can be taxed without influencing the level of investment, because it can be attributed to advantages, such as favorable head starts, patents, inventions, or some form of natural monopoly - in other words, entrepreneurial advantages not enjoyed by competitors.

On this basis, three kinds of CT regimes can be distinguished:

- The conventional CT regime that takes equity income or profits as its base and that permits a deduction for interest paid on debt;

- A CT regime that taxes equity income and interest (jointly called capital income) at the level of the corporation; and

- A CT regime that is confined to the above-normal rate of return by allowing a deduction from profits of the normal return (as well as interest).

Table 1 displays the various CT-regimes that embody these three approaches and that are discussed below. ${ }^{3}$ The Table also indicates that profits are usually taxed in the source country (that is, the country in which corporations carry on their business), while residual (personal) income tends to be taxed in the residence country (that is, the country in which the corporation's shareholders reside). This distinction is relevant, because source-country taxation affects the corporation's investment location decision. ${ }^{4}$ Further, most CTs interact with the personal income tax (PT) imposed on residual income, whether dividends, interest or capital gains. Capital gains arise if profits are retained in the corporation, which pari passu increases the value of the corporation's shares. Taxing dividends and capital gains again at shareholder level involves double taxation, which may not be desirable, especially with regard to the normal rate of return.

\section{[here about Table 1]}

The following sections discuss each of the various CT bases in greater detail. ${ }^{5}$

\footnotetext{
${ }^{3}$ For a somewhat different characterization, see Auerbach, Devereux, and Simpson (2010), which refers to Devereux and Sørensen (2006). For an early overview, see also OECD (2007). It should be emphasized that in practice the various types of income discussed here may be difficult to distinguish from each other. Thus, profits may represent the return to entrepreneurial labor that is retained in the firm and realized as dividends or capital gains (Gordon and Hausman, 2010; see also below under dual income taxation). Further, it may be difficult to distinguish rents from the delayed returns on past investment (quasi-rents), whose taxation affects investment incentives. Another example are the returns that accrue through tax deductible stock options which do not show up as profits. For a useful treatment, see Griffith and Miller (2014).

${ }^{4}$ Generally, the location of investment is influenced by the effective average CT rate, the volume of investment by the effective marginal tax rate, and the location of profits by the statutory rate.

${ }^{5}$ For a discussion of the rationale for taxing corporations, see Cnossen (2015) on which the remainder of this section draws.
} 


\subsection{Taxing Profits}

Although economic theory prescribes that corporate profits should be calculated on an accretion basis, ${ }^{6}$ in practice taxable profits are determined on the basis of International Financial Reporting Standards (IFRS), which is the European-wide rule since 2005 for corporations listed on EU stock exchanges. The accounting principles prescribe that revenues and costs should be matched on an annual basis under the accrual system of accounting. The costs of raw materials, intermediate goods and wages, as well as expenses, including interest, in earning taxable profits and in maintaining the assets used in the corporation's activities are deductible. Further, prospective losses are taken into account in computing taxable profits, but accrued capital gains are not taxed until they are realized.

The taxation of profits interacts with the PT of shareholders in a variety of ways as shown below.

\subsubsection{Classical system}

Under the classical system (Van den Tempel, 1970), the corporation is regarded as an entity entirely separate from its shareholders and taxed as such. Accordingly, no deduction for dividends distributed to shareholders is allowed in computing taxable profits. Instead, those distributions are taxed again in full in the hands of shareholders at rates that differ from one shareholder to another - depending on the amount of the dividend and the shareholders' other income - but that may range from the lowest to the highest marginal rate of the progressive PT.

The phenomenon of taxing equity income at corporate as well as shareholder level is called the 'economic double taxation of dividends." 7 Double taxation tends to generate a bias against profit distribution and in favor of debt financing. The CT and the PT on equity income both enter the wedge between the before-tax return of the corporation and the required after-tax return (the reward for saving) that must be paid to shareholders to induce them to put up their capital. This double tax affects entrepreneurial behavior, because the wedge (and, by extension, the required return) will vary, depending on the choice of financing (retained profits, new equity, or debt) and the corporation's dividend policy (distribution or retention). ${ }^{8}$

\subsubsection{Full integration}

Single taxation is achieved under full integration, which views the corporation as a conduit of the equity income, distributed as well as retained profits, of shareholders. Full integration is one of the normative implications of the accretion concept of income, as formulated by Schanz, Haig, and Simons (S-H-S-concept). ${ }^{9}$ If income is

\footnotetext{
${ }^{6}$ The economic concept defines profits as the difference between assets and liabilities valued at market prices at the beginning and the end of the year, adjusted for profit distributions and capital contributions or pay-outs. Under the economic concept, economic depreciation would replace accounting depreciation and capital gains and losses would be taxed or compensated as they accrue. In the presence of inflation, moreover, adjustments would have to be made to the real value of the outstanding debt. The economic concept of profits is a very challenging design desideratum that is extremely difficult to put into practice.

${ }^{7}$ For the seminal treatment of the double taxation issue, see McLure (1979).

${ }^{8}$ The alleged economic distortions of the classical system have not gone unchallenged in the finance literature as well as the public finance literature (Head, 1997). For a brief account and references to the literature, see Cnossen (2015).

${ }^{9}$ For the classic exposition of the S-H-S income concept, see Goode (1975). For the normative inference of full integration, see Musgrave and Musgrave (1984), 33 and 386-388.
} 
defined all inclusively, it is argued, there should be no difference between corporate profits or other capital income, such as interest and rental income, and labor income, such as wages and salaries, which is solely subject to the PT. There is no place, therefore, for an extra tax on distributed profits nor, it should be added, for the preferential treatment of profits retained by the corporation and taxed below the marginal PT rate of shareholders. Full integration has been considered by the Royal (Carter) Commission on Taxation (1966) in Canada, the US Department of the Treasury (1977 - Blueprints; 1992), and the Campbell Committee (1981) in Australia. These plans, however ingenious, have never left the drawing board, primarily because they are considered impractical (McLure, 1979; US Department of the Treasury, 1992). ${ }^{10}$

\subsubsection{Dividend relief systems}

Full integration has been characterized as the search for a perfect solution in an imperfect world. As a halfway house to the ideal of full integration, various dividend relief systems have been designed under which at least distributed profits are taxed in accordance with the shareholder's marginal income tax rate. Relief can be provided at the shareholder or the corporate level as illustrated by the following variants.

\section{- Imputation system}

At the shareholder level, dividend relief can be provided systematically (that is, proportionate to the marginal PT rates of shareholders) under the imputation system, which permits shareholders a full or partial credit against their PT for the CT that can be imputed to the dividends, grossed-up by the tax credit, received by them.

Imputation systems used to dominate the CT picture in the EU, especially in the 1970s and 1980s. Over time, however, they were regarded as overly complicated, while their cross-border implications were held to be discriminatory. ${ }^{11}$

\section{- Dividend-deduction system}

The most obvious approach to the double-taxation issue is to permit dividends as a deduction from taxable profits, as is the case with interest, under what is called the dividend-deduction system. A full deduction makes the system equivalent to an undistributed profits tax with which the US briefly, and not altogether favorably, experimented in the 1930s. A small deduction moves the system closer to the classical CT. Unless the goal is to stimulate equity investment by non-residents, a drawback of the dividend deduction system is that the relief is automatically extended to foreign shareholders (and exempt entities), who do not pay the (additional) national PT incurred by domestic shareholders. ${ }^{12}$

\footnotetext{
${ }^{10}$ Of course, full integration is practiced under the 'partnership method' of Subchapter S of the U.S. Internal Revenue Code. S corporations with 100 shareholders or less enjoy the benefit of incorporation while being taxed as a partnership. Cooper, et al (2015) estimate that "pass-through" businesses, such as partnerships and S-corporations (heavily concentrated among high-earners) generate over half of U.S. business income.

${ }^{11}$ Thus, in Manninen, the European Court of Justice (2004) held that the Finnish imputation system violated the free movement of capital principle laid down in the Treaty of Rome (1957), because the imputation tax credit was not available to dividends received from foreign corporations. Hence, the Court argued, this deterred taxable persons in Finland from investing in other Member States. For a detailed review of imputation systems, see Cnossen (1997).

12 The US Department of the Treasury (1984) included a proposal for a 50 percent deduction (later reduced to 10 percent) for dividends paid. Interestingly, the automatic extension of the benefit to nonresidents was seen to be positive, because the resulting increase in the incentive for inward foreign investment would help finance the US deficit on current account.
} 


\section{- Split-rate system}

Under the split-rate system, distributed profits are taxed at a lower rate than retained profits. Of course, if the rate differential is small, the split-rate system resembles the classical CT, and if the differential is large the CT again becomes an undistributed profits tax. A disadvantage of the split-rate system (without a withholding tax complement) is that foreign parent companies with domestic subsidiaries can avoid the higher rate on retained profits by first distributing the subsidiary's earnings and then channeling them back as equity for reinvestment purposes. In the early 1970s, this consequence bedeviled the German split-rate CT. ${ }^{13}$

- Ad hoc approaches

Under less structured forms of dividend relief, net dividend income is taxed at a flat PT-rate in the hands of shareholders, lower than the top marginal PT rate.

Alternatively, part of net dividend income is exempt for PT purposes. Clearly, an objection to these forms of dividend relief is that the benefit is distributed regressively with respect to income. Nevertheless, as shown below, ad hoc approaches are the most common form of dividend relief in the EU.

\subsection{Taxing Capital Income}

Under conventional CT regimes, interest is not treated on par with the return on equity, even if debt and equity are fully substitutable. Equal treatment is achieved under regimes that tax the returns on both equity and debt at the corporate level, ${ }^{14}$ either provisionally in the form of a dual income tax (DIT) or definitively under a comprehensive business income tax (CBIT).

\subsubsection{Dual income tax}

Under the DIT, all income is split into either capital income or labor income. Capital income, individual as well as corporate, is taxed at the moderate, uniform CT rate. The reason is that capital income is more mobile than labor income (hence, moderation in rate setting is indicated) and that tax arbitrage is more prevalent (suggesting uniform taxation). For revenue and equity reasons (perhaps human capital tends to be distributed more unevenly than financial capital), labor income is taxed at progressive PT rates. Further, taxing capital income separately from labor income implies that the capital income tax rate (= CT rate) is not held hostage to the high, progressive PT (including social security contributions) on labor income. In fact, a separate capital income tax provides governments with an additional policy tool to respond to changes in international capital mobility and the tax policy of other countries.

Although most CT-regimes in the EU tax capital income separately from labor income on an ad hoc basis, this is done systematically under the DITs in the Nordic countries, especially Finland, Norway and Sweden, ${ }^{15}$ which now have 25 years of

\footnotetext{
${ }^{13}$ Cnossen (2015) shows that the split-rate system, the dividend deduction system and the imputation system can provide the same degree of tax relief expressed as a percentage of the classical degree of over-taxation. The most important assumption underlying this result is that payout rates are not affected by the choice of the dividend relief system.

${ }_{14}^{14}$ Arguably, this applies to most royalty payments, too.

${ }^{15}$ The DIT was pioneered in Denmark in 1987, but subsequently the country strayed from the DIT path by moving some way back to a comprehensive income tax.
} 
experience with dual income taxation. Norway’s DIT comes closest to a pure DIT. ${ }^{16}$

Details of a pure DIT can be found in Box $1 .{ }^{17}$ Three features deserve attention. First, the level of the creditable withholding tax on interest paid by corporations can vary in light of domestic and international policy considerations (for instance, its effect on foreign domestic investment (FDI)). The rate of withholding could be lower than the CT rate, for instance, and not apply to foreign recipients of interest. Presumably, full (and final) withholding on interest paid to foreign as well as domestic bondholders, would require international coordination.

\section{[here about Box 1]}

Secondly, the presumptive return for calculating the capital income component of the taxable profits of proprietorships and closely-held companies can be applied to the value for tax purposes of all business assets, called the gross method (Norway), or to the equity capital (the value of all assets minus liabilities) of the business, referred to as the net method (Finland). ${ }^{18}$ As explained by Sørensen (2010), the choice between the two methods is largely a choice between investment neutrality and minimizing opportunities for tax arbitrage. Tax arbitrage is less of an issue under the gross method, because the presumptive rate of return is applied to a base that is not influenced by the financing structure of the business. The net (equity) method, on the other hand, is more conducive to investment neutrality because it does not encourage debt-financed investment if the government sets the presumptive rate of return above the going interest rate.

Thirdly, the Norwegian DIT makes a distinction between the normal return on capital and economic rents by subjecting above-normal returns on shares to the progressive PT on labor income. This shareholder income tax (Sørensen, 2005) taxes dividend income in full under the PT but permits a deduction of a rate of return allowance equal to the interest on medium term government bonds. Accordingly, this rate of return allowance is taxed only once, namely at corporate level, while economic rents are taxed twice. This approach eliminates the incentive for income shifting between labor and capital income under the DIT in a manner that does not distort investment incentives. ${ }^{19}$ Furthermore, it obviates the need to make a distinction between "active

\footnotetext{
${ }^{16}$ Outside the Nordic area, various countries have also introduced DIT elements in their tax systems, as shown by Eggert and Genser (2005) and Genser and Reutter (2007). Further, the German Council of Economic Experts (2003), Sinn (2004), and Spengel and Wiegard (2004) have proposed variants of the DIT for Germany. Keuschnigg and Dietz (2007) did so for Switzerland and Griffith, Hines and Sørensen (2010) touch on the issues in the Mirrlees Review. Kleinbard (2010) provides a very thorough analysis of the DIT in the US context.

${ }^{17}$ For a review and evaluation of the economic and technical aspects of the dual income tax on which this section draws, see Cnossen (2000) and Sørensen (2010). For an earlier analysis, see Sørensen (ed.) (1998).

${ }^{18}$ Under the gross method, the presumptive return is reduced by the interest actually paid to calculate taxable net capital income. The gross return, furthermore, is subtracted from total profits (increased by the interest actually paid) to calculate taxable labor income. Under the net method, in contrast, presumptively determined capital income is subtracted directly from net profits (that is, net of interest actually paid) to ascertain taxable labor income.

${ }^{19}$ As a result, as noted by Kleinbard (2010), Norway does not make a distinction between labor and capital income, but between the normal return on capital and all other income. Peter Sørensen pointed out to me, however, that income of privately held immovable property still is fully taxed at progressive rates.
} 
owners" of closely-held companies (owning the business as well as managing it, that is, earning labor income) and "passive owners" (financing, but not owning the business and not involved in running it). ${ }^{20}$ The distinction between labor and capital income remains relevant, however, for unincorporated businesses, but only if the sum exceeds the first bracket of the labor income tax schedule, whose rate equals or approximates the CT rate.

\subsubsection{Comprehensive business income tax}

The ambivalence of the DIT regarding the taxation of interest is removed under the Comprehensive Business Income Tax (CBIT), proposed by the US Department of the Treasury (1992). The CBIT treats interest on par with dividends by not allowing a deduction at corporate level in conjunction with an exemption for both income items at the level of the recipients, be they individuals, corporations or exempt entities. Capital gains on shares would only be taxed to the extent that they exceed the acquisition cost stepped up by the corporation's retained profits net of CT. In the US version of the CBIT, the rate would be set at the same level as the top PT rate, so that the business income tax would serve as the final withholding tax on dividend and interest. Extending the CBIT to proprietorships and partnerships - more difficult to achieve - would also make the distinction between corporations and non-corporate entities irrelevant for tax purposes. ${ }^{21}$

The CBIT, as proposed, would reduce the relative tax burden on new equity-financed investment and increase the burden on debt-financed investment. Established firms and institutional investors would face relatively higher tax burdens, as would tax haven countries, but new, growing firms, would be taxed less heavily. Unlike the DIT, the CBIT has not been introduced in any country, presumably because of its effective taxation of all interest whether paid to domestic or foreign bondholders. ${ }^{22}$ Taxing foreign bondholders might deter inward capital flows. Further, the CBIT does not envisage the application of a progressive PT on labor income, which may be considered desirable for revenue and distributional reasons.

\subsection{Taxing Economic Rents}

The income-based CT regimes discussed above tax the opportunity cost of capital. If it is not considered desirable, however, that the CT interferes with the level of investment, only 'pure profits' or 'economic rents' should be taxed. In the literature, a tax on the pure profits of an investment is associated with cash-flow taxation, which comes in three guises: as a cash-flow tax per se, as an allowance for corporate equity (ACE), and as a rate of return allowance (RRA). ${ }^{23}$

\footnotetext{
${ }^{20}$ On the possibilities of income shifting under the (previous) Norwegian DIT, see Alstadsaeter (2007). Pirttilä and Selin (2011) argue that income shifting is still an issue in Finland.

${ }^{21}$ For probing comparative analyses and evaluations of the DIT, CBIT, as well an ACE-system (see below), see Sørensen (2007), and Radulescu and Stimmelmayr (2007).

${ }^{22}$ For a discussion, see Collins and Edgar (2013). A similar fate seems to have befallen on the Business Enterprise Income Tax (BEIT) proposed by Kleinbard (2007). The BEIT entails a cost of capital allowance (COCA) for both equity and debt at business level equal to a normal rate of return. This allowance would be taxable at the level of investors, while above-normal returns would be taxed at business level. For a critique of the BEIT, see Warren (2008) and Collins and Edgar (2013).

${ }^{23}$ The Meade Committee (1978) has shown that a tax on the flow of funds into and out of any investment is equivalent in present value terms to an annual pure profits tax levied over the lifetime of the investment.
} 


\subsubsection{Cash-flow or flat tax}

Under the cash-flow tax, corporations are denied a deduction for interest as well as dividends paid (if not already denied), but they would be allowed an immediate writeoff of the cost of business assets. ${ }^{24}$ As a result, the return on marginal investments, just making a viable economic return, would not be taxed. This would ensure investment neutrality if the government were to share symmetrically in all gains and losses under unlimited loss carry-forward and backward provisions. ${ }^{25}$

The cash-flow tax is identical to a subtraction-VAT type of origin-based direct tax, called flat tax, which has been proposed in the US (Hall and Rabushka, 1995). Under the flat tax, value added, consisting of wages and business cash flow, is determined by deducting purchases (including investment goods) from sales. Subsequently, wages are deducted and taxed separately at the employee's level. What remains are abovenormal or pure profits. This origin-based type of cash flow tax would still distort the location of corporate activity if CT rates differ between countries. As first proposed by Bond and Devereux (2002), this distortion can be avoided if the origin-based variant were converted into a destination-based tax by permitting border tax adjustments (imports taxed, exports free of tax) for goods and services entering into international trade, just as under the VAT. ${ }^{26}$

\subsubsection{Allowance for corporate equity (ACE)}

The allowance for corporate equity (ACE) is the best known type of cash-flow tax in Europe. ${ }^{27}$ The ACE system purports to tax only pure profits by providing a deduction from profits, conventionally computed, equal to the shareholders' funds (generally, the corporation's total equity capital, including taxable profits net of CT) multiplied by an appropriate nominal interest rate set by the government but reflecting a normal market rate of return on, say, medium-term government bonds. Since the ACE approximates normal profits, its deduction from total taxable profits means that the CT would be confined to pure profits from infra-marginal investments.

Proponents of the ACE approach (Devereux and Freeman (1991); and Gammie (1991)) point out that in present value terms the base of the CT would be identical to the base of an annual pure profits tax for two reasons. First, the equity allowance permits any schedule of depreciation allowances without altering the present value of the tax payments associated with the cash flow of an investment. High depreciation allowances would result in a lower amount of shareholders' funds and hence a lower

\footnotetext{
${ }^{24}$ This would be the so-called real ( $\mathrm{R}$ base) cash flow tax. Under a real and financial ( $\mathrm{R}+\mathrm{F}$ base) variant, in(de)creases in borrowing and interest paid/received would also be taken into account. Further, under a share form of cash flow tax ( $\mathrm{S}$ base $=\mathrm{R}+\mathrm{F}$ base), the repurchase/issue of own shares and dividends paid/received would be accounted for. See Meade Committee (1978).

${ }^{25}$ For arguments why cash flow taxation has economic and administrative advantages over a conventional income tax, see McLure and Zodrow (1996). Becker and Fuest (2005) show that the revenue effects would be manageable if Germany were to place its CT on a cash flow basis.

${ }^{26}$ As pointed out to me by Devereux, the objective of destination-based taxation can also be achieved by increasing the VAT rate and reducing taxes on labor income, say, employer's social security contributions. Revenue losses, transitional difficulties, international problems (for example, obtaining a foreign tax credit for it), and fear of the unknown seem to preclude the adoption of a destinationbased cash-flow tax, which is perhaps also true for the source-based variant.

${ }^{27}$ The ACE system was conceived by Boadway and Bruce (1984) and given hands and feet by the Institute for Fiscal Studies (1991).
} 
allowance and vice versa. Second, both corporations and shareholders can borrow at the appropriate nominal interest rate to offset different profiles of tax payments or distributions, respectively. Furthermore, the ACE approach preserves neutrality under inflation, because the interest rate is set at its full nominal level.

Undoubtedly, the ACE system has attractive neutrality properties. ${ }^{28}$ The neutrality conditions, however, are met only if capital markets are perfect. Further, if dividends continue to be taxed under PTs, the ACE system would favor retentions even more strongly over distributions than do partial integration systems. In effect, the ACE system would resemble a form of dividend relief, akin to the dividend-deduction system, but this time confined to a kind of primary dividend. Also, the ACE regime does not provide relief to unincorporated businesses. To be fully neutral, the ACE system requires the transformation of the PT into a personal consumption tax, which comprehensively exempts the normal return to capital. ${ }^{29}$

In comparing the ACE system with the CBIT, Bond (2001) opines that in a world with increasing mobility of physical capital, the user cost of capital may no longer be the only route through which the CT influences the level of domestic investment. If, as is likely, multinational companies dominate in the earning of economic rents, their discrete location decisions would also be influenced by the statutory rate or, more precisely, the Effective Average Tax Rate (EATR) which can be shown to be a weighted average of the statutory tax rate and the Marginal Effective Tax Rate (METR). Under an equal-yield assumption, the statutory rate would have to be higher under the ACE tax, which would distribute corporate tax payments towards relatively profitable companies. By contrast, a lower-rate CBIT would leave profitable multinational companies with lower tax bills. In this situation, a government in an open economy may achieve a higher level of domestic investment by lowering the statutory rate and accepting a broader tax base, even though this results in a higher cost of capital. In a broader and more probing analysis, De Mooij and Devereux (2010) argue that a combination of ACE and CBIT reforms can be designed to be revenue neutral and welfare improving through smaller financial distortions.

\subsubsection{Rate of Return Allowance (RRA)}

The extension of the ACE to non-corporate investments is being achieved under Mirrlees et al's (2011) proposal of a Rate of Return Allowance (RRA) for all capital income; in other words, a reduction of the gross rate of return on all investments in whatever form with a normal rate of return equal to, say, ACE. ${ }^{30}$ Clearly, the RRA transforms the CT/PT into a personal consumption tax or, at business level, the cash flow component of a broad-based VAT (see Section 2.4.1 above) which does not tax the normal return either but only the above-normal or inframarginal return. This makes the RRA a neutral tax which does not influence the intertemporal consumption choice and hence the decision to save or invest now or in the future. As Mirrlees et al

\footnotetext{
${ }^{28}$ For the UK, De Mooij and Devereux (2009) have shown that the adoption of ACE financed by a base-broadening of the VAT (food and the construction of new dwellings are zero-rated in the UK, while rent on dwellings is exempt) would result in an increase of investment by $6.1 \%$ and wages by $1.7 \%$. Further, employment would increase by $0.2 \%$ and GDP by $1.4 \%$.

${ }^{29}$ Indeed, this kind of reform was recommended by the IFS Capital Taxes Group (1989) in the form of an extended personal equity plan.

${ }^{30}$ Note that this RRA differs from the Norwegian variant, which taxes the normal return. For a detailed proposal to move the current Canadian corporate tax to a rent-based tax, see Boadway and Tremblay (2014).
} 
(2011) point out, above-normal returns can be taxed progressively since doing so does not influence savings and investment behavior.

The goal of neutral capital income taxation can also be approximated by what the US Department of the Treasury (1977), calls the Exempt/Exempt/Taxed (EET) method and the Taxed/Exempt/Exempt (TEE) method. The EET-method exempts savings out of current income as well as the return on the savings, but taxes withdrawals in full. This is the treatment that applies to savings for retirement purposes, such as pensions, for instance. The second approach can be likened to the tax treatment of durable consumer goods, such as cars and houses: the savings for the purchase are taxed, but the return is not subject to the PT and neither is the sale.

On the assumption of a constant PT rate and a constant rate of interest (= discount rate), the present value of the tax payments and disposable incomes, separately and jointly, will be the same under both methods. But, as Auerbach (2012) points out, if these assumptions are relaxed, the TEE method has the disadvantage that abovenormal returns (as reflected in capital gains) are not taxed. The drawback of the EET method is that it is rather sensitive to changes in tax rates, which may influence savings propensities. The deduction of an ACE or RRA at the business or individual level does not suffer from these shortcomings. But the problem with these allowances is that they have to be set by government (and are thus subject to pressure by lobby groups) and that the relating assets have to be monitored.

In practice, the choice between these three approaches (ACE/ RRA, EET, TEE) will depend on the kind of asset that is being taxed. ACE seems to be the method of choice to ensure investment neutrality at the business level, while EET, TEE and RRA make it possible to achieve approximate equal treatment at the level of the individual with respect to: (a) pensions (EET: contributions and returns of pension funds exempt from tax but payouts taxed; (b) savings deposits (TEE: taxed when deposits are set aside out of income, but interest and withdrawals exempt under the assumption that deposits do not generate above-normal returns); and (c) investments in shares, bonds and real estate (RRA: taxed when savings are made, returns (including capital gains) that exceed the normal return taxed (taking into account the CT that has already been levied in the case of shares), sales exempt. Under the Mirrlees et al (2011) proposal, the exemption of the normal return paves the way for the integration of the PT (including above-normal return on capital) and social security contributions without income ceiling.

\subsection{Comparative evaluation}

The most fundamental difference between the three main regimes is that CTs that take profits or capital income as their base tax the normal return to capital, whereas CTs that confine the base to business cash flow do not. Hence, the latter regimes do not affect real investment. Also, financing decisions - choosing between equity and debt or retained earnings and new equity - are not distorted, while the distortion of the organizational form in which the business is conducted - corporate vs. non-corporate form - is mitigated. However, not taxing the normal return implies that the CT rate has to be higher if CT revenues are to be maintained. This would exacerbate tax avoidance through profit shifting. 
The arguments for taxing the normal return to capital are neatly summed up by Jacobs (2013). The optimality arguments for not taxing the normal return do not appear to be persuasive if bequests are not taxed and present and future consumption are not weakly separable (Atkinson and Stiglitz, 1976). Banks and Diamond (2010) emphasize labor income uncertainties and heterogeneous saving preferences as arguments for taxing the normal return to capital . Nielsen and Sørensen (1997) argue that a progressive PT causes distortions in the supply of human capital, which can be mitigated by a tax on capital. Jacobs (2013) brings equity arguments to the fore for taxing the normal return. Income inequality is not only attributable to inequalities in earning capacity, but also to inequalities in capital endowment, which should be corrected on distributional grounds. Further, it has been pointed out that the distortions of taxing the normal return are small and that market imperfections may make the taxation of capital income attractive. Last but not least, the body politic seems to favor the taxation of the normal return. The way forward, therefore, seems to lie with CT regimes that tax the normal rate of return, even though consumptionbased regimes appear to score better on neutrality grounds. ${ }^{31}$

The difference between CTs on equity income and CTs on capital income is that the latter regime provides for the equal treatment of profits and interest, which should reduce spillovers and prevent tax avoidance. Comprehensive inclusion of interest is achieved under the CBIT, while the DIT does not tax the interest paid on foreign investment or applies a lower rate. Hence, there is a presumption that the CBIT distorts financing and organizational choices less than the DIT. On an equal-yield assumption, the CT rate could also be lower under the CBIT. The choice between DIT and CBIT is further clarified below following an assessment of actual CT-regimes in the EU and a review of the criteria that should govern tax relationships between EU Member States.

\section{Current Tax Treatment of Corporate Source Income}

This section surveys CT regimes in the EU in light of the taxonomy developed above. As noted, the CTs are largely source-based taxes, which, presumably, induces rate competition between Member States involving reduced revenues. This has been called a race to the bottom. Accordingly, the section starts with a brief sketch of the trends in CT rates and revenues. Subsequently, CT regimes are analyzed by type and by the tax treatment of capital gains, interest and royalties. The main findings conclude.

\subsection{Trends in CT rates and revenue}

Following the liberalization of capital markets in the early 1990s, the simple average CT rate declined by 12\%-points or about one-third, from on average 35\% in 1995 to 23\% in 2014 (see Figure 1 and Eurostat, 2014). By contrast, CT ratios (revenues as a percentage of GDP) hardly declined. Since 1995, the arithmatic average ratio for 27 Member States (excluding Croatia) dropped from 2.8\% to 2.5\% in 2013. ${ }^{32}$ Revenue even peaked around 2007, although rates had already been lowered to around their current level. Apparently, the statutory rate reductions were offset by base broadening measures (for instance, reduced depreciation allowances), increased incorporation of

\footnotetext{
${ }^{31}$ Griffith, Hines and Sørensen (2010) also point out that the US government has signaled that it is not prepared to offer a foreign tax credit for cash flow taxes paid abroad by US multinationals.

${ }^{32}$ Note that the CT ratios do not include revenues from PTs on capital gains, interest and royalties.
} 
firms (shifting income from PTs to CTs), and an increase in the profitability of the corporate sector (Griffith and Miller, 2014). ${ }^{33}$

\section{[Figure 1 about here]}

Obviously, effective CT rates (and consequently revenues) are the product of nominal rates and tax bases. To gain some insight in the various tax bases, the Annex to the paper provides an overview of the major profit determination rules in the EU Member States. In all Member States, capital costs are recovered by way of a variety of straight-line and declining-balance methods, based on historical cost, at widely varying rates. LIFO (last-in-first-out), FIFO (first-in-first-out) and average cost methods (not shown) are used to value inventories. LIFO tends to be more favorable in times of rising prices, because the last purchased unit is deemed to be sold first which should reduce book profits compared with FIFO which assumes that the first unit bought is deemed to be sold first. Furthermore, about half of all Member States permit a general provision for doubtful debts (calculated as a percentage of total accounts receivable). Loss carry-forward provisions tend to be generous, but only six countries permit losses to be compensated with profits of earlier years. The impact of this restriction is mitigated in some cases by allowing groups of related companies (generally defined by reference to ownership criteria) to be taxed on a consolidated basis.

Further, the Annex lists various restrictions on profit shifting that Member States impose and that shore up the source country's taxing rights. The measures comprise compulsory debt-equity ratios that limit interest payments to related companies (located at home or abroad), rules that restrain the manipulation of transfer prices between related companies in order to shift profits to low-tax Member States, and rules that prohibit the deferral of tax on the source income of controlled foreign corporations (CFCs). Finally, all Member States exempt pension and investment funds from tax, which, in the absence of the effective taxation of interest, should provide them with an incentive to prefer bonds over shares.

Finally (not shown in the Annex), in all Member States, the tax base is eroded by a variety of tax incentives (provisions that provide special treatment to qualified investment projects not available to investment projects in general) primarily to promote entrepreneurship and stimulate innovation. The incentives take the form of tax holidays and reduced rates, accelerated investment recovery allowances and tax credits, and R\&D incentives. The latest tax invention is a patent box in which the whole or part of profits attributable to new inventions are taxed at a lower effective CT rate or not at all, and which reduces the tax on wages paid to researchers. In a recent study covering 12 European countries, Evers, Miller and Spengel (2015) conclude that $R \& D$ regimes that allow expenses to be deducted at the ordinary CT rate, as opposed to the lower patent box rate, may result in negative effective average tax rates and can thereby provide a subsidy to unprofitable projects. Last but not least, a study sponsored by the European Commission (2014; Straathof, project leader) notes that the profits from patents are protected and hence in the nature of rents, which hardly justifies favorable tax treatment.

\footnotetext{
${ }^{33}$ Egger and Ruff (2015) find that countries have responded to the rate reductions by rival governments by reducing their statutory tax rates and lowering depreciation allowances. Interestingly, the authors suggest that the rise in tax competition has been caused by regional trade integration.
} 


\subsection{Treatment of corporate source income}

Following an overview, the types of CT/PT regimes are discussed, as well as the tax treatment of capital gains, interest and royalties.

\section{2 .1 Overview}

Table 2 provides an overview of the tax treatment of corporate source income at corporate level and share- and debt-holder level in the EU Member States. The average CT-rate of $23 \%$ conceals widely different individual-state rates, ranging, in 2016, from a low of $10 \%$ in Bulgaria to a high of $38 \%$ in France. Interestingly, CT rates in the 13 new states are on average some 4\%-points lower than in the 15 old Member States. This suggests that new Member States use their CT rates more aggressively in stimulating investment in the corporate sector than old Member States. ${ }^{34}$ Similarly, individual country CT ratios differ widely, ranging from $1.2 \%$ in Slovenia to $6.5 \%$ in Cyprus, a tax haven country.

\section{[Table 2 about here]}

As indicated in Table 2, CT regimes tend to be defined by the way they treat equity income, in particular profit distributions, that is, dividends, which may be taxed twice or exempted at shareholder level (but for a possible withholding tax at corporate level). The PT rate on capital gains (reflecting, among others, undistributed profits after CT) is also shown in Table 2 as are the withholding taxes on interest and royalties paid to domestic recipients. For comparative purposes, the last column lists the top PT rate on other income, generally labor income. ${ }^{35}$

\subsubsection{Types of CT/PT regimes}

The following types of CT/PT regimes are found in the EU.

- The so-called classical double taxation system is found in four Member States. The double tax is particularly high in Spain where the combined CT+PT burden takes up three-fifths of dividend income. Under the classical regime in Lithuania, on the other hand, the combined CT+PT burden is merely $28 \%{ }^{36}$ The differentially higher combined taxes are likely to distort financing decisions and dividend payout policies. Old equity (retained profits) tends to be favored over new equity and profit retentions over profit distributions.

- Two Member States, Malta and the UK, employ an imputation system. The relief is expressed as a fraction (or percentage) of the net dividend. Malta has a full imputation system, which means that distributed profits are taxed at the marginal PT rate of shareholders. ${ }^{37}$ In the UK, the relief is so small that the effective CT+PT burden differs little from the burden under double taxation.

\footnotetext{
${ }^{34}$ On the other hand, agglomeration may also matter: some old Member States are larger than most peripheral states. See Baldwin and Krugman (2004), and Garretsen and Peeters (2007).

${ }^{35}$ For a similar earlier version, see Cnossen (2005). In comparing the information in this publication with the data in the current paper, the most noteworthy development is the replacement of dividend exemption schemes by final withholding taxes at corporate level on dividends as well as interest. ${ }^{36}$ According to Table 2, CT+PT rates in Bulgaria (14.5\%), Estonia (20\%), Latvia (23.5\%), the Netherlands (25\%) and Cyprus (27.4\%) are also lower than in Lithuania.

${ }^{37}$ More than full relief is possible if dividends are paid out of exempt profits without imposing a compensatory tax at the corporate level. Presumably, for this reason, Malta imposes a $15 \%$ tax on dividends paid out of untaxed profits.
} 
In both countries, imputation serves as a withholding device. Not surprisingly, therefore, neither country subjects profit distributions to a withholding tax.

- Two countries, Finland and Sweden, may be said to have a DIT, although the regimes are not as pure as the Norwegian system. ${ }^{38}$ Under DITs, capital and labor income are taxed separately, permitting the imposition of flat final source taxes, as is done in Finland. Corporate profits and other capital income are taxed at (approximately) the same moderate flat rate. However, capital gains are taxed twice in Finland and Sweden to the extent that no account is taken of the CT that is levied on retained profits.

- Fifteen Member States, including Germany, exempt dividends in the hands of domestic shareholders but levy a final (non-creditable) withholding tax at corporate level. Interest is also subject to final withholding taxes. Accordingly, the withholding features resemble the DIT, except that the combined CT+PT burden on dividends is higher than the burden on interest income.

Since dividends are taxed fully at corporate level without regard to the PT rate structure, the relief in the form of a flat final withholding tax is proportionately greater for high-income-bracket PT payers than for low-income-bracket PT payers. Austria, Germany and Portugal mitigate this regressive effect by permitting low-income-bracket PT payers to opt for full double taxation of their dividend income (with a credit for any PT withholding tax imposed at the corporate level). Interestingly, final withholding on both dividends and interest turns the various CTs into CBITs.

- Two Member States, including France, exempt dividend income, either fully or partially, in the hands of shareholders. Partial exemption method does not permit the imposition of a final withholding tax at corporate level, because the potential tax liability at shareholder level is not known. Note that the Netherlands views its $1.2 \%$ net wealth tax (which it calls income tax and which is not shown in the table) as a substitute for the PT on dividend income that it abolished in the 2001 tax reform. ${ }^{39}$

- Belgium exempts the normal return from CT in the form of an ACE, called "notional interest on corporate capital.” The interest is set at the rate payable on 10-year government bonds issued in the previous year; presumably, this rate approximates the normal rate of return on capital. The rate $-1.63 \%$ in 2016 but 2.13\% for SMEs - is applied to the corporation's "risk capital," that is, its equity shown on the balance sheet. Belgium introduced the ACE system to stimulate the self-financing capability of corporations, but did not extend it to unincorporated businesses and private investors. ${ }^{40}$ Italy confines the ACE to

\footnotetext{
${ }^{38}$ For a discussion of the Norwegian system, see Sørensen (2010), and for an analysis of the Finnish system (OECD, 2008).

${ }^{39}$ The 2001 tax reform (Cnossen and Bovenberg, 2001) exacerbated the discrimination against equity holdings. The return on equity is now taxed twice, under the CT and the presumptive PT, while the return on debt is taxed only once, under the PT.

${ }^{40}$ In an analysis of the Belgian system, Aus dem Moore (2014) shows that the expected reduction in leverage is confined to large firms.
} 
new equity. For some time, Croatia also had an ACE system but abolished it for reasons that are not entirely clear (Keen and King, 2002).

- Estonia goes even further than Belgium by exempting the whole of corporate profits from CT. Instead, a $20 \%$ tax is levied upon the distribution of corporate profits to individuals or other corporate entities. The profits distribution tax has not eliminated CT revenues in Estonia, which were 1.4 percent of GDP in 2012 (Eurostat, 2014) and have declined to 0.3\% in 2013.

In approximately half of all Member States, the CT+PT on distributions out of current profits is higher than the PT on labor income.

\subsubsection{Taxation of capital gains}

Double taxation also occurs when retained profits are subject to the CT and again to the PT in the form of capital gains tax on increases in share values - increases that, among others, reflect the corporation's greater net worth as a result of profit retention. As shown in Table 2, 22 Member States tax capital gains on shares, but no Member State makes a systematic attempt to alleviate the double tax on retained profits by allowing shareholders to increase the acquisition price of shares by the corporation's retained profits net of CT (as Norway does). Further, the capital gains tax rates shown in Table 2 are statutory or nominal rates. Deferral and various tax base preferences result in effective capital gains tax rates that are lower than the nominal rates and also lower than the CT+PT burden on profit distributions. Accordingly, shareholders should have a preference for capital gains over dividends, which may be expected to affect pay-out policies.

Of further interest is that at least 13 Member States make a distinction between capital gains realized on the sale of ordinary (widely-held) shares (generally, quoted on national stock exchanges) and capital gains realized on the sale of other (non-traded) shares, which often represent a controlling interest (called substantial holding) in (closely-held) corporations. These Member States apply differentially higher taxes on dividends and capital gains of shares belonging to a substantial holding (variously defined), because these gains often represent labor income of manager-shareholders sheltered in corporate form at a CT rate that is lower than the marginal PT rate on other labor income. Details can be found in Table 3. As noted above, Nordic dual income taxes provide the most consistent treatment of capital income and labor income that accrue jointly in proprietorships, partnerships and closely-held corporations.

\section{[here about Table 3]}

\subsubsection{Tax treatment of interest and royalties}

While equity income is mainly taxed at source, in principle interest and royalty income is taxed at the level of the recipient. If the recipient is an individual residing in the same jurisdiction, the interest and royalty income would be taxed at the recipient's marginal PT rate. If the recipient is an exempt entity, say, a pension or investment fund, the interest or royalty payments would not be taxed. Further, tax administrations in source countries cannot enforce the tax on domestic source income paid to nonresidents. 
In practice, as shown in Table 2, a majority of Member States impose a final withholding tax on interest paid to domestic recipients, including, presumably, exempt entities. This seems less common in the case of royalties. Double tax treaties have to be consulted for the treatment of non-resident recipients. Most Member States exempt EU residents of other Member States from withholding taxes on interest and royalties if they are effectively subject to tax. Under the interest and royalty directive (COM(2003)841) related companies of different Member States with cross shareholdings of at least $25 \%$ are exempt from withholding tax if the beneficial owner is effectively subject to tax on interest and royalties received in the corporation's Member State of establishment. Accordingly, there would still be an incentive for corporations to borrow in high-CT Member States.

\subsection{Main findings}

This review of the taxation of corporate source income in the EU yields some broad conclusions that are useful in assessing the current CT regimes and the various alternatives that have been proposed.

- Although CT rates have declined substantially in recent years, CT ratios have not changed. In other words, there is no race to the bottom in terms of revenue.

- There are wide differences in the rules for ascertaining taxable profits. Concessionary CT rates, generous cost recovery allowances, and liberal R\&D allowances reduce effective CT rates.

- The taxable return on corporate investments is defined in terms of equity income (profits), but increasingly, Member States levy final withholding taxes on dividends and interest - income items that are subsequently exempted at share- and debt-holder level (final withholding taxes on royalty payments are less common). In other words, many CT regimes are moving towards some form of DIT under which the withholding tax is not levied on interest payable on foreign debt.

- Generally, dividends are taxed higher than interest if the earlier CT is taken into account, as it should be. Capital gains are widely taxed at schedular PT rates and only upon realization, involving lower effective rates. Profit retentions tend to be favored over profit distributions.

- Thirteen Member States reinforce the CT's backstop function of the PT by separate taxes on the capital gains of shares in closely-held companies, which can be used to shelter PT-liable labor income.

- In all Member States, pension and investment funds are not taxed and can hence be used as conduits for not paying tax on interest or dividends if tax is not withheld at corporate level or the withholding taxes on these payments are refundable.

- Member States have a strong preference for source-based taxation and shore this principle up with transfer pricing rules, prescribed debt-equity ratios and CFC regimes. Interestingly, unlike withholding taxes on interest payments to domestic debt-holders, debt-equity ratios effectively limit interest payments to foreign debt-holders, too.

Overall, the review suggests that in most Member States there is no integrated view on the taxation of capital income that considers the tax treatment of equity and debt income jointly or that comprehensively exempts the normal return on capital. Rather, the picture is that of a modified conventional corporate income tax under which 
corporations and share- and debt-holders are all taxed separately without much consideration of double or non-taxation issues. This should give rise to various spillovers as discussed in the next section.

\section{Subsidiarity and Neutrality in Corporate Taxation}

A fundamental evaluation of the CT regimes and, more broadly, capital income taxation in the EU should have regard to the subsidiarity and neutrality principles laid down in the EU Treaty. Who should tax, what, and where? ${ }^{41}$

\subsection{Subsidiarity issues}

The cross-border spillover effects of individual Member State decisions regarding capital income taxation, and thus the need for concerted coordination, depend importantly on the way debt and equity are in fact allocated across different Member States. Under current rules, capital income crossing EU (and third country) borders may be taxed under either the source principle or the residence principle (Musgrave, P.B., 1987).

Both principles have their pros and cons. If capital income is taxed according to the residence principle, a country can tax its residents on the basis of their worldwide income. Hence, in line with the ability-to-pay criterion, it can apply a progressive tax. Furthermore, the residence principle permits capital export neutrality (CEN), which implies that the tax system does not affect the choice between investing at home or abroad (Musgrave, R.A., 1969). Administratively, however, the residence principle is difficult to put into practice. Residence countries typically cannot enforce compliance with the (correct) return of foreign-source income - especially if the source country does not cooperate and profits are retained in the source country. Moreover, taxpayers faced with a high tax bill on their worldwide income may migrate.

The source principle is generally applied with respect to corporate profits, usually on the basis of the philosophy that the source state has created the economic conditions under which real investment can flourish. ${ }^{42}$ Moreover, the source principle promotes capital import neutrality (CIN). This implies that both resident and non-resident investors face the same tax burden on an investment in a particular source country. The source principle is easier to apply in practice than the residence principle because the taxable income originates in the Member State collecting the tax. Hence, the taxing state can enforce the tax more easily. Difficulties arise, however, in connection with the determination of proper arm's length prices for cross-border transactions between related firms and with the allocation of joint overhead costs of those firms.

In a situation of perfect capital mobility, the residence principle equalizes pre-tax rates of return; in other words, at the margin, capital costs are the same in different countries. The source principle, in contrast, tends to equalize the post-tax rates of

\footnotetext{
${ }^{41}$ This section draws heavily on Cnossen and Bovenberg (1997).

${ }^{42}$ The CT is difficult to justify as a proxy for government-supplied benefits. Instead, properly designed user charges would be indicated to capture the cost of providing these benefits. More importantly, if the CT were indeed a proxy for the cost of government-supplied services, the tax would not be distortionary and coordination would not be needed.
} 
return of savers residing in different states. Whether one principle is economically superior to the other principle depends on whether users of capital (business firms) or suppliers of capital (savers) are more sensitive to differences in returns. Business firms are likely to be more sensitive to differences in capital costs than savers are to differences in net returns. Hence, the residence principle (that is, capital export neutrality) seems a more important efficiency objective to pursue than the source principle (that is, capital import neutrality). ${ }^{43}$

In practice, both principles are applied in the EU. Retained profits are taxed at source. Most residence states tax shareholders on realized capital gains. Dividends are taxed not only by the source state (under the CT and by withholding taxes, if any) but also by the residence state (under the PT and CT on portfolio dividend income). The return on debt, that is, interest, is taxed by the residence state and, if a withholding tax applies, by the source state. If the source state does not levy a withholding tax, interest income may escape taxation altogether - for instance, if it accrues to a tax exempt investor, is channeled through a tax haven, or is not included in the tax return. These considerations apply also to the returns on know-how, that is, royalties.

The current application of the source and residence principles in the EU yields two major implications regarding the subsidiarity requirement. First, the source principle appears to dominate tax base allocation. This is understandable because tax sovereignty is closely associated with the tax base originating in the source country. In the absence of full exchange of tax information (which can be viewed as violating tax subsidiarity), administrative considerations also dictate a heavy reliance on the source principle. Second, tax subsidiarity is jeopardized by the divergent tax treatment of the return on equity, which is taxed at corporate level, and the return on debt, which may not be taxed at all. As will be emphasized in the next section, growing capital mobility and financial innovation facilitate the substitution of debt for equity and, therefore, reinforce the revenue implications of the divergent treatment of debt and equity.

\subsection{Neutrality shortcomings}

External neutrality (between Member States) requires internal neutrality (within Member States) - an important lesson from VAT harmonization. In particular, domestic distortions, such as the tax bias against profit distributions, inhibit free intraEU capital movements. Moreover, the exclusive focus on external neutrality (with respect to 'mobile' factors) leaves domestic distortions unchanged, especially the discrimination against equity income and small, starting enterprises. These aspects are discussed below.

\subsubsection{Discrimination of profit distributions}

The distortionary effects of taxing profit distributions twice depends on the marginal source of equity finance (that is, either retained profits or new equity). If firms finance their marginal investments through profit retention rather than new shares, they have to reduce dividends that would otherwise be available for distribution. Accordingly,

\footnotetext{
${ }^{43}$ In an early contribution, Horst (1980) showed that if the elasticities of supply and demand for capital are positive but finite, the optimal tax lies somewhere between the point that ensures capital export neutrality and the point that conforms to capital import neutrality. It should be noted that CEN is not achieved if residence countries limit the foreign tax credit and if they defer domestic tax on the business income of foreign subsidiaries until repatriation.
} 
the role of dividends is crucial. In this connection, the literature has developed two hypotheses, which are known as the 'traditional view' and the 'new view' (Sinn, 1991; and Zodrow, 1991).

The traditional view argues that dividends offer non-fiscal benefits. Dividends provide a signal to shareholders, for instance, that all is well with the company, or they may limit financial discretion and hence potential misuse of funds by management (Jensen and Meckling, 1976). At the margin, the corporations equalize the tax disadvantages and non-tax advantages of profit distributions. Accordingly, a new investment will in part be financed by issuing new shares, because dividends cannot be lowered without cost. $^{44}$ This implies that the higher (total) tax burden on dividend income compared with retained profits discourages new investment and distorts the dividend-payout decision.

The 'new view' denies the existence of non-tax advantages associated with profit distributions. Accordingly, the higher tax on dividend income should cause corporations to prefer profit retentions over new share issues as the marginal source of finance. Profit retention enables shareholders to enjoy the return on the new investment in the form of tax-preferred capital gains. Moreover, they save on the PT on dividend income that they would have had to pay if profits had been distributed rather than retained. The capitalized value of this saving is exactly equal to the discounted value of the tax on distributed profits that must be paid in the future. Therefore, the tax on dividends does not distort investment decisions - at least if the corporation generates sufficient profits to finance marginal investments through retained profits, and the tax rate on dividends is expected to remain constant in the future.

Most empirical studies support the traditional view (Zodrow, 1991). Furthermore, an important implication of the new view is that the market value of corporate assets exceeds existing share values. This does not seem to be the case. Whatever view is adopted, taxing dividends twice always harms investment by new businesses, which have to rely on new share issues to provide for their equity needs. ${ }^{45}$ The discrimination of new equity under the classical system and the partial imputation systems, therefore, contributes to the concentration of market power by discouraging the entry of new firms. It is especially detrimental to small, growing firms that provide an important impetus to technological innovation.

\subsubsection{Preferential treatment of debt}

The combined PT/CT burden on debt equals the PT-rate on interest income, while the combined burden on retained earnings is the sum of the CT-rate and the capital gains tax rate. Without an examination of a country's tax system, it is difficult to judge whether debt or retentions are taxed more heavily. However, the growing internationalization and liberalization of capital markets implies that the tax system

\footnotetext{
${ }^{44}$ As Zodrow (1991) notes, the assumption that marginal investments are financed with new shares is made more plausible if 'issuing new shares' is understood to include reductions in share repurchases or takeovers, or the issuance of short-term debt that will ultimately be repaid with new share issues. For another view, see Sinn (1991). For a review of the literature on the new view, see Auerbach and Hassett (2007).

${ }^{45}$ It applies also to firms in which dividends are an important signaling device because management is far removed from shareholders. In this situation, dividend reduction in any one year would be costly to management.
} 
favors debt over retentions, because it increases opportunities for evading or avoiding the PT on interest income. ${ }^{46}$ Whereas retained earnings are taxed at source through the CT, the tax authorities cannot be sure that cross-border interest payments are reported and taxed.

Furthermore, the internationalization of capital markets increases the scope for tax arbitrage involving debt finance. ${ }^{47}$ Indeed, capital income may possibly be subsidized if lightly taxed assets are financed with loans, the interest of which is deductible against taxable income in a country with high tax rates. Opportunities for tax arbitrage grow because continued financial innovation makes debt and equity increasingly close substitutes. This puts increased pressure on the distinction between debt and equity.

The tax exempt status of institutional investors, such as pension funds, also facilitates the preferential treatment of the return on debt. Typically, interest income accruing to pension funds is not taxed (neither is dividend income, but such income is taxed at source under the CT). In addition, the tax-exempt status of institutional investors affects their portfolio choice and thereby the ownership structure of firms. In particularly, institutional investors tend to prefer bonds to shares, as the prices of shares, which yield a large part of their return in the form of untaxed capital gains, are bid up by taxable investors. The best way to prevent a distorted ownership structure is to tax the return on debt and equity more even-handedly.

Furthermore, the tax-favored status of debt discriminates against companies that face difficulties in attracting debt, because they do not yet enjoy a high credit rating, own mainly non-liquid assets (such as firm-specific machinery) against which it is difficult to borrow, or generate insufficient taxable profits to be able to deduct interest. Consequently, these firms, which tend to be young and small, have to incur higher capital costs on account of taxation than do older, established firms with easier access to debt financing or sufficient retained profits to finance new investments. Finally, the favorable treatment of debt may make the economy more vulnerable to recessions, because it may lead to excessive borrowing which increases the risk of bankruptcies. ${ }^{48}$

\subsection{Cross-border effects}

The domestic distortions described above yield important EU-wide implications. First, the high tax on dividends, which stimulates profit retention, reduces the amount of capital becoming available on European capital markets and thus hampers the development of EU share markets. ${ }^{49}$ Second, investments by old firms financed through retained earnings tend to yield a lower (before-tax) return. Third, the bias in favor of old firms inhibits the entry of new firms. Accordingly, the tax system

\footnotetext{
${ }^{46}$ In addition, inflation stimulates debt finance, because nominal, rather than real, interest expenses are deductible from taxable profits.

${ }^{47}$ For a useful treatment, see De Mooij (2012), who proposes an ACE system to treat equity income on par with interest. The revenue cost could be reduced by limiting the allowance to new investment.

${ }^{48}$ To the extent that debt has not become a perfect substitute for equity, the non-tax costs of borrowing have not been eliminated. However, the efficiency effect is ambiguous (Auerbach, 1990).

${ }^{49}$ Just like the double tax on dividends, the tax treatment of pension premiums in Germany interferes with EU-wide capital mobility. Most pension premiums are deductible from taxable profits in Germany only if retained in the firm as so-called book reserves. This tax treatment provides established German firms with relatively cheap equity finance at the expense of new starting firms (not only in Germany but also in other Member States) that have to attract new equity.
} 
infringes on competitive conditions, thereby jeopardizing the dynamics of the single market. Moreover, taxing profit distributions twice discriminates in favor of Member States with many mature firms (which do not need new equity). Furthermore, it confers an artificial advantage on Member States with companies that conform to the 'conduit' model of the firm (with shareholders managing the company) and, therefore, do not need to distribute a large portion of their profits to satisfy shareholders.

The preferential treatment of debt also favors Member States with institutions (banks and large firms with liquid assets) that allow substantial debt finance. For instance, German banks often act as holdings that are closely involved with the activities of German businesses. Thus, in Germany, the high CT-rate (or, previously, the lower rate on distributed profits plus the higher withholding rate) does not discourage domestic investment, but mainly acts as a protective device against foreign takeovers and foreign ownership of domestic firms, because foreigners do not have the same easy access to bank finance.

Time and again, the European Commission's reports fail to discuss the implications of the domestic distortions of the various CTs for EU-wide neutrality. ${ }^{50}$

\subsection{Conclusion}

The subsidiarity principle indicates a preference for source country taxation over residence-country taxation of corporate source income in the EU. By implication, capital import neutrality is favored over capital export neutrality. In a single market, however, in which capital and persons can move freely, the distinction between these two kinds of neutrality tends to become blurred. Administrative considerations, moreover, support the argument for source-country taxation. ${ }^{51}$ Further, the experience in federal countries, such as the U.S. and Canada indicates that different CTs can exist in a single market without internal borders. ${ }^{52}$

Although various efforts have been made in recent years to reduce the discrimination of profit distributions by lowering the PT on dividends, and the preferential treatment of debt by imposing (final) withholding taxes at corporate level, most neutrality shortcomings have not yet been eliminated fully or have been removed through ad hoc measures (for example, debt-equity ratios) that leave the basic conventional CTs largely intact. Perhaps the time has come to consider more fundamental options for CT coordination, as discussed in the next and last section.

\section{Implications for Corporate Tax Reform and Coordination}

\footnotetext{
${ }^{50}$ For a very useful study on world-wide spillover effects, see International Monetary Fund (2014).

${ }^{51}$ For administrative reasons, source country taxation is also indicated if Capital Ownership Neutrality (CON) is the policy goal. This concept, developed by Desai and Hines (2003), posits that cross-country ownership patterns should not be distorted by the tax system. CON may be attained under worldwide foreign-credit income taxation and tax base harmonization, but also under a territorial system with tax base harmonization. Obviously, feasibility considerations favor the latter approach. Interestingly, the US President's Advisory Panel on Federal Tax Reform (2005) advocated that the US should move to a territorial system for the taxation of corporate income by exempting dividends paid out of active foreign business income.

52 These countries, however, have an overarching federal CT, which should iron out some of the differences in state and provincial CTs.
} 
The previous section has argued that subsidiarity and neutrality in the EU are best served by the moderate, even-handed, source-country taxation of all capital income. ${ }^{53}$ A moderate rate is recommended, because in an open economy with perfect capital mobility, any source-based tax on the normal return to capital will be shifted onto domestic immobile factors of production, such as labor and land. In practice, corporate capital (real investment) is not perfectly mobile, but the degree of international mobility is high, and this is a key argument for keeping any source-based tax low. ${ }^{54}$ Furthermore, capital market innovation in conjunction with tax arbitrage implies that it is hardly feasible to tax capital income at different rates. If for revenue and distributional reasons, it is not possible to lower the top PT rate to the level of the lower CT rate, the obvious solution therefore is to tax capital income on a schedular basis. As Table 2 shows, this is already the case in many Member States, albeit on an ad hoc basis.

Specifically, a pragmatic scenario for further capital income (including CT) tax reform and coordination could comprise three sequential steps, moving from DIT to CBIT.

- The introduction of a DIT by each Member State under which all capital income would be taxed once at a single rate (different for each Member State) to mitigate the distorting effects of current differential CT+PT systems on corporate financial and investment policies. Agreement could be pursued on a minimum DIT rate. Under the DIT, dividend should be subject to a moderate final withholding tax at the corporate level but exempted at the personal level. This is already the case in many Member States. As in Norway, the final withholding tax can be said to represent a differentially higher tax on abovenormal profits which accrue mainly to shareholders.

- The extension of final interest (and royalty) withholding taxes throughout the EU to payments to non-residents as well as residents to effectively tax the normal return to capital, and to eliminate incentives for thin capitalization and the discrimination in favor of tax exempt investment and pension funds. Eventually, the withholding taxes should be raised to the level of the DIT rate, which would convert the DIT into a CBIT. ${ }^{55}$ Agreement should be reached that interest (and royalties) are not taxed again in residence countries. ${ }^{56}$ To ensure that dividends and interest are not paid out of exempt earnings (and

\footnotetext{
${ }^{53}$ In an early publication Slemrod (1995) argued that an EU featuring (equal-rate) source-based DITs would be more efficient than an EU featuring fully enforced residence-based taxes (if feasible of implementation) only, because the cost of enforcement is lower for the system of source-based taxes. ${ }^{54}$ For further arguments in favor of moderate, uniform capital income tax rates, see Zodrow (2006, 2010).

${ }^{55}$ If, under CBIT, corporations were allowed to write off the cost of capital goods, the CBIT would in fact become a cash flow tax: only economic rents would be taxed while the return on marginal investments would be exempted.

${ }^{56}$ In a very thorough survey, Finke, et al (2014) assess the impact of various measures to strengthen source taxation in OECD member countries. Four options are discussed: bilaterally restricting interest and royalty deductibility, replacing the deductibility of payments by an inverted tax credit system (Lodin, 2011, 2013), levying withholding taxes on all interest and royalty payments, and levying withholding taxes as an anti-avoidance regulation. In this connection, it may be noted that the ACE allowance might be given consideration if express or tacit coordination on taxing capital income at source cannot be achieved, yet the existing bias against equity is a serious problem.
} 
thus escape the tax altogether), a compensatory tax should be levied on exempt income made available for distribution as dividends or interest. Capital gains on shares should only be taxed to the extent that they exceed the acquisition cost stepped up by the corporation's retained profits net of the CT.

- The approximation of CT (and withholding) rates throughout the EU would eliminate incentives for transfer pricing manipulation (and thin capitalization). Presumably, rate approximation would be easier to achieve following the introduction of DITs and interest withholding taxes. This would make the debt-equity distinction irrelevant, and greatly reduce the distinction between retained and distributed profits (depending on the treatment of capital gains).

These measures would reduce the relative tax burden on new equity-financed investment and increase the burden on debt-financed investment. Established firms and institutional investors would face relatively higher tax burdens, as would tax haven countries, but new, growing firms, would be taxed less heavily. If the reform were revenue neutral, average tax rates could be allowed to fall due to overall efficiency gains. The comprehensive and final withholding taxes on interest under the DIT would raise capital costs and dampen debt-financed (foreign) investment, because the normal return on capital, even if received by exempt entities and nonresidents, would be implicitly taxed. Although taxation of interest at corporate level would seem a goal worth pursuing, gradual and concerted action is called for. Caution is advisable because the current tax-induced changes in corporate financing patterns may, to a large extent, serve to reduce the distortions of real investment and saving decisions.

Under this proposal, the EU DITs would still proceed from the separate-accounting approach in determining the taxable profits of affiliated corporations in different Member States. Accordingly, provisions for the removal of cross-border obstacles to economic activity and business restructuring would still be needed. As pointed out by the European Commission (2001), a comprehensive solution to these problems, if desired, can only be achieved through common base taxation. The advantages of common base taxation with formula apportionment (and its logical conclusion, unitary taxation) are fewer distortions, less tax arbitrage, and lower compliance costs. But the path to common base taxation would not be easy. As pointed out by McLure and Weiner (2000) its introduction would give rise to serious policy-sequencing and transition problems for EU Member States. Accounting conventions and institutional structures would have to be harmonized. All of these problems would be exacerbated by complex technical questions, such as defining a unitary business, choosing the appropriate apportionment formula, and measuring the factors in the formula. ${ }^{57}$ Harmonization of the tax base is less urgent than coordination of the tax rates. Perhaps formulary apportionment should therefore be left for two or more Member States to deal with as is the case in the U.S. and Canada.

This scenario does not envisage a European DIT (or CBIT) as the completion of the CT coordination process. As an overarching tax, a European DIT would mitigate the distortions of the DITs of the Member States. A truly European DIT, however,

\footnotetext{
${ }^{57}$ Using a numerical computable general equilibrium (GCE) model for Europe, Bettendorf, et al (2010) find that common base taxation does not yield substantial welfare gains and does not weaken incentives for tax competition.
} 
administered by a joint administration under a common code uniformly interpreted by the European Court of Justice, would require fundamental changes in the EU's constitution moving it in the direction of a federal (tax) system. For the time being, this seems a bridge too far.

To conclude, this paper has focused on tax neutrality tempered by subsidiarity considerations in an internal market with high capital mobility. The solution that has been explored, however, also yields important equity implications. Maintaining comprehensive, residence-based, progressive taxes on capital in a world of capital mobility, inevitably results in complex, fragmentary, and ineffective taxes on capital income that violate horizontal and vertical equity norms. In that context, across-theboard source taxation of capital income, admittedly at lower rates than labor income is taxed, ensures a greater degree of effective equity.

\section{References}

Altstadsaeter, A. (2007), The Achilles Heel of the Dual Income Tax: The Norwegian Case, 20 Finnish Economic Papers 1, 5-22.

Atkinson, A.B. and J.E. Stiglitz (1976), 'The Design of Tax Structure: Direct versus Indirect Taxation', 6 Journal of Public Economies 1-2, 55-75.

Auerbach, A.J. (1990), Debt, Equity, and the Taxation of Corporate Tax Flows, in J.B. Shoven and J. Waldfogel (eds.), Taxes, Debt and Corporate Restructuring, Washington, D.C.: Brookings Institution.

Auerbach, A.J. (2012), The Mirrlees Review: A U.S. Perspective, 65 National Tax Journal 3, 685-708.

Auerbach, A.J., M.P. Devereux, and H. Simpson (2010), Taxing Corporate Income, chapter 9 in S. Adam, T. Besley, R. Blundell, S. Bond, R. Chote, M. Gammie, P. Johnson, G. Myles, and J. Poterba (eds.), Dimensions of Tax Design: The Mirrlees Review, Oxford University Press for the Institute for Fiscal Studies, 837-893.

Auerbach, A.J., and K. Hassett (2007), The 2003 Dividend Tax Cuts and the Value of the Firm: An Event Study, in A. Auerbach, J. Hines, and J. Slemrod (eds.), Taxing Corporate Income in the $21^{\text {st }}$ Century, Cambridge, U.K.: Cambridge University Press.

Aus dem Moore, N. (2014), Corporate Taxation and Investment - Evidence from the Belgian Ace Reform, Ruhr Economic Paper No. 534 (December 17).

Baldwin, R.E., and P. Krugman (2004), Agglomeration, Integration and Tax Harmonisation, 48 European Economic Review, 1-23.

Banks, J., and P. Diamond (2010), The Base for Direct Taxation, chapter 6 in S. Adam, T. Besley, R. Blundell, S. Bond, R. Chote, M. Gammie, P. Johnson, G. Myles, and J. Poterba (eds.), Dimensions of Tax Design: The Mirrlees Review, Oxford University Press for the Institute for Fiscal Studies, 548-648.

Becker, J., and C. Fuest (2005), Does Germany Collect Revenue from Taxing the Normal Return to Capital? 26 Fiscal Studies 4, 491-511.

Bettendorf, L., M.P. Devereux, A. van der Horst, S. Loretz, and R.A. de Mooij (2010), Corporation Tax, Economic Policy, July.

Boadway, R., and N. Bruce (1984), A General Proposition on the Design of a Neutral Business Tax, 24 Journal of Public Economics, 231-239.

Boadway, R. and J-F. Tremblay (2014), Corporate Tax Reform: Issues and Prospects for Canada, Mowat Research \#88. Toronto: Mowat Centre at the University of Toronto. 
Bond, S. R. (2001), Levelling up or Levelling Down? Some Reflections on the ACE and CBIT Proposals, and the Future of the Corporate Tax Base, chapter 7 in S. Cnossen (ed.), Taxing Capital Income in the European Union: Issues and Options for Reform, Oxford: Oxford University Press, 161179.

Bond, S.R., and M.P. Devereux (2002), Cash Flow Taxes in an Open Economy, CEPR Discussion Paper, No. 3401.

Campbell Committee (1981), Final Report of the Committee of Inquiry into the Australian Financial System. Canberra: Australian Government Publishing Service (AGPS).

Cnossen, S. (1997), The Role of the Corporation Tax in OECD Member Countries, 49-84 in J. Head and R. Krever, eds., Company Tax Systems, Melbourne: Fiscal Publications.

Cnossen, S. (2000), Taxing Capital Income in the Nordic Countries: A Model for the European Union? chapter 8 in S. Cnossen, ed., Taxing Capital Income in the European Union: Issues and Options for Reform, Oxford University Press, 180-213.

Cnossen, S. (2003), Is the VAT's Sixth Directive becoming an anachronism? European Taxation (December), 434-442.

Cnossen, S. (2005), The Future of Corporate Income Taxation in the European Union, in Capital Taxation after EU Enlargement, Proceedings of OeNb Workshops, Vienna: Oesterreichische Nationalbank.

Cnossen, S. (2015), What Kind of Corporation Tax Regime?, 52 Osgoode Hall Law Journal 2, 513551.

Cnossen, S., and A.L. Bovenberg (1997). The Ruding Report: Some Further Thoughts, 164-178 in Mario I. Blejer and Teresa Ter-Minassian, eds., Macroeconomic Dimensions of Public Finance: Essays in honour of Vito Tanzi, London: Routledge.

Cnossen, S., and L. Bovenberg (2001), Fundamental Tax Reform in the Netherlands, 8 International Tax and Public Finance 4, 471-484.

Collins, K.A. and T. Edgar (2013), The Carter Report's Corporate Income Tax Proposals: Why They Were Rejected and an Assessment of the Current Canadian System as in Imperfect Alternative, in K. Brooks, ed., The Quest for Tax Reform Continues: The Royal Commission on Taxation Fifty Year Later, Carswell, 115-154.

Cooper, M., J. McClelland, J. Pearce, R. Prisinzano, J. Sullivan, D. Yagan, O. Zidar, and E. Zwick (2015), Business in the United States: Who owns it and how much tax do they pay? NBER Working Paper Series, Working Paper 21651.

De Mooij, R.A. (2012), Tax Biases to Debt Finance: Assessing the Problem, Finding solutions, 33 Fiscal Studies 4, 489-512.

De Mooij, R.A. and M.P. Devereux (2010), Alternative Systems of Business Tax in Europe: An Applied Analysis of ACE and CBIT Reforms, Working Paper No. 17, Brussels: European Commission.

Desai, M.A., and J. Hines, Jr. (2003), Evaluating International Tax Reform, 56 National Tax Journal, 487-502.

Devereux, M. and H. Freeman (1991), A General Neutral Profits Tax, 12 Fiscal Studies 3, 1-15.

Devereux, M.P., and P.B. Sørensen (2006), The Corporate Income Tax: International Trends and Options for Fundamental Reform, Economic Papers No. 264, Brussels: European Commission, Directorate-General for Economic and Financial Affairs. 
Eggert, W. and B. Genser (2005), Dual Income Taxation in EU Member Countries, CESifo DICE Report 3 (1), 41-47.

Eggar, P., and H. Ruff (2015), Tax Rate and Tax Base Competition for Foreign Direct Investment, 22 International Tax and Public Finance, 777-810.

Ernst \& Young (2016), Worldwide Personal Tax Guide: Income tax, social security and immigration 2015-16. Available on the internet.

European Commission (1998), Code of Conduct, based on the Conclusions of the ECOFIN Council Meeting concerning taxation policy, Official Journal of the European Communities (98/C 2/01), January 6, 1998.

European Commission (2001), Communication from the Commission to the Council, the European Parliament and the Economic and Social Committee - Towards an Internal Market without tax obstacles - A strategy for providing companies with a consolidated corporate tax base for their EUwide activities, Brussels, COM (2001) 582.

European Commission (2014), A Study on R\&D Tax Incentives, Final Report, Taxation Paper N. 52, Luxembourg: Official Publications of the European Communities.

European Commission (2015), Corporate Income Taxation in the European Union, Commission Staff Working Document, Brussels, COM(2015) 302 final.

European Court of Justice (2004). Manninen, Case C-319/02, September 7.

Eurostat (2010, 2014, 2015), Taxation trends in the European Union: Data for the EU Member States, Iceland and Norway, Brussels: Taxation and Customs Union.

Evers, L., H. Millar, and C. Spengel (2014), Intellectual Property Box Regimes: Effective Tax Rates and Tax Policy Considerations, 10 International Tax and Public Finance, on line.

Finke, K., C. Fuest, H. Nusser, and C. Spengel (2014), Extending Taxation of Interest and Royalty Income at Source - An Option to Limit Base Erosion and Profit Shifting? ZEW Discussion Papers, No 14-073, Center for European Economic Research, University of Mannheim, Germany.

Gammie, M. (1991), Corporate Tax Harmonisation: An “ACE” Proposal: Harmonising European Corporate Taxation Through An Allowance for Corporate Equity, European Taxation (August), 238242.

Garretsen, H., and J. Peeters (2007), Capital Mobility, Agglomeration and Corporate Tax Rates: Is the Race to the Bottom for Real? 53 CESifo Economic Studies 2, 263-293.

Genser, B., and A. Reutter (2007), Moving Towards Dual Income Taxation in Europe, 63 FinanzArchiv 3, 436-456.

German Council of Economic Experts (2003), Staatsfinanzen konsolidieren - Steuersystem reformieren, Annual Report 2003/04, as amplified in German Council of Economic Experts and Max Planck Institute for Intellectual Property, Dual Income Tax: A Proposal for Reforming Corporate and Personal Income Tax in Germany, ZEW Economic Studies.

Goode, R. (1975), The Individual Income Tax, Washington, DC: Brookings Institution.

Gordon, R.H., and J. Hausman (2010), ‘Commentary’ in J. Mirrlees, et al. (eds.), Dimensions of Tax Design: The Mirrlees Review, Oxford: Oxford University Press for the Institute for Fiscal Studies.

Griffith, R., and H. Miller (2014), Taxable Corporate Profits, 35/4 Fiscal Studies, 535-557.

Griffith, R., J.R. Hines, and P.B. Sørensen (2010), International Capital Taxation, in J. Mirrlees et al (2010), Dimensions of Tax Design: The Mirrlees Review, Oxford: Oxford University Press 
Hall, R.E. and A. Rabushka (1995), The Flat Tax, $2^{\text {nd }}$ ed. Stanford, CA: Hoover Institution Press.

Harding, M. (2013), Taxation of Dividend, Interest, and Capital Gain Income, OECD Working Papers, No. 19, Paris: OECD Publishing.

Head, J. G. (1997), Company Tax Structure and Company Tax Incidence, International Tax and Public Finance 4, 61-100.

Horst. T. (1980), A Note on the International Taxation of Investment Income, 94 Quarterly Journal of Economics (June), 793-798.

IFS Capital Taxes Group (1989), Neutrality in the Taxation of Savings: An Extended Role for PEPs, Commentary no. 17. London: Institute for Fiscal Studies.

Institute for Fiscal Studies (1991), Equity for Companies: A Corporation Tax for the 1990s, IFS Commentary No. 26. London: Institute for Fiscal Studies.

International Bureau for Fiscal Documentation (2016), Microsoft Internet Explorer, Europe Corporate Taxation and Europe - Individual Taxation. Accessed January 2016.

International Monetary Fund (2014), Spillovers in International Corporate Taxation, IMF Policy Paper, Washington, DC.

Jacobs, B. (2013), From Optimal Tax Theory to Applied Tax Policy, 69 FinanzArchiv 3, 338-389.

Jensen, M.C., and W.H. Meckling (1976), Theory of the Firm: Managerial Behavior, Agency Costs and Ownership Structure, 3 Journal of Financial Economics 4, 305-360.

Keen, M. and J. King (2002), The Croatian Profit Tax: An ACE in Practice, 23/3 Fiscal Studies 401418.

Keuschnigg, C., and M.D. Dietz (2007), A Growth-oriented Dual Income Tax, 14 International Tax and Public Finance, 191-221.

Kleinbard, E.D. (2007), Rehabilitating the Business Income Tax, Washington, DC: The Brookings Institution Hamilton Project.

Kleinbard, E.D. (2010), An American Dual Income Tax: Nordic Precedents, 5 Northwestern Journal of Law \& Social Policy 1, 40-86.

Lodin, S-O. (2011), Intragroup Lending in Sweden - A Vehicle for International Tax Arbitrage, Tax Notes International, 177-180.

Lodin, S-O. (2013), Intragroup Royalties as a Vehicle for International Tax Arbitrage, Tax Notes International, 1317-1319.

McLure, Jr., C.E. (1979), Must Corporate Income Be Taxed Twice? Washington, DC: Brookings Institution.

McLure, Jr., C.E. and J.M. Weiner (2000), Deciding Whether the European Union Should Adopt Formulary Apportionment of Company Income, chapter 10 in S. Cnossen (ed.), Taxing Capital Income in the European Union: Issues and Options for Reform, Oxford: Oxford University Press.

McLure, Jr., C.E. and G.R. Zodrow (1996), A Hybrid Consumption-Based Direct Tax for Bolivia, 3 International Tax and Public Finance 97-112.

Meade Committee (1978), The Structure and Reform of Direct Taxation, London: Allen and Unwin.

Mirrlees, J., et al. (2010), Dimensions of Tax Design: The Mirrlees Review, Oxford: Oxford University Press. 
Mirrlees, J., et al. (2011), Tax by Design, The Mirrlees Review, Oxford: Oxford University Press.

Musgrave, P.B. (1987), Interjurisdictional coordination of taxes on capital income, chapter 7 in S. Cnossen (ed.), Tax Coordination in the European Community, Deventer, The Netherlands: Kluwer, Series on International Taxation, 197-225.

Musgrave, R.A. (1969), Fiscal Systems, New Haven: Yale University Press.

Musgrave, R.A., and P.B. Musgrave (1984), Public Finance in Theory and Practice, New York: McGraw-Hill.

Nielsen, S.B., and P.B. Sørensen (1997), On the Optimality of the Nordic System of Dual Income Taxation, 63 Journal of Public Economics, 311-329.

Neumark Committee (1962), Report of the Fiscal and Financial Committee, in International Bureau of Fiscal Documentation: EEC Reports on Tax Harmonization, unofficial translation by H. Thurston, Amsterdam (1963).

OECD (2007), Fundamental Reform of Corporate Income Tax, Paris.

OECD (2008), Setting tax policies that support the Nordic model, chapter 3 in OECD Economic Surveys: Finland, 55-83.

OECD (2010), Model Convention with respect to Taxes on Income and on Capital, Paris.

OECD (2010a), OECD Transfer Pricing Guidelines for Multinational Enterprises and Tax Administrations, Paris: July.

OECD (2014), OECD TAX DATABASE, Explanatory Annex, Part II: Taxation of Corporate and Capital Income (updated May).

Pirttilä, J., and H. Selin, Income Shifting within a Dual Income Tax System: Evidence from the Finnish Tax Reform of 1993, 113 Scandinavian Journal of Economics 1, 120-144.

PriceWaterhouseCoopers (2016), Worldwide Tax Summaries Corporate Taxes 2015/16, PWC on line.

Radulescu, D.M. and M. Stimmelmayr (2007), ACE versus CBIT: Which is Better for Investment and Welfare? 53 CESifo Economic Studies 2, 294-328.

Royal (Carter) Commission on Taxation (1966), Report. Ottawa: Queen’s Printer.

Ruding Committee (1992), Company Taxation in the Internal Market, COM(2001)582final, Brussels: European Commission.

Sinn, H-W. (1991), Taxation and the Cost of Capital: The 'Old' View, the 'New' View and Another 'View,' 25-54 in D.F. Bradford (ed.), Tax Policy and the Economy 5, Cambridge, MA: MIT Press.

Sinn, H-W. (2004). Ist Deutschland Noch zu Retten?, Munich: Econ Verlag, 5th ed.

Slemrod, J.L. (1995), Free Trade Taxation and Protectionist Taxation, 2 International Tax and Public Finance, 471-489.

Sørensen, P.B., ed. (1998), Tax Policy in the Nordic Countries, Macmillan, London.

Sørensen, P.B. (2005), Neutral Taxation of Shareholder Income, 12 International Tax and Public Finance, 777-801.

Sørensen, P.B. (2007), The Nordic Dual Income Tax: Principles, Practices, and Relevance for Canada, 55/3 Canadian Tax Journal 557-601. 
Sørensen, P.B. (2010), Dual Income Taxes: A Nordic System, chapter 5 in I. Claus, N. Gemmell, M. Harding and D. White, eds., Tax Reform in Open Economies, Edward Elgar, London.

Spengel, C. and W. Wiegard (2004), Dual Income Tax: A Pragmatic Tax Reform Proposal for Germany, CESifo Dice Report, 2/3 Journal for Institutional Comparisons 9-14.

US Department of the Treasury (1977), Blueprints for Basic Tax Reform. Washington, DC: US Government Printing Office.

US Department of the Treasury (1984), Tax Reform for Fairness, Simplicity, and Economic Growth, Washington, D.C.: US Government Printing Office.

US Department of the Treasury (1992), Integration of the Individual and Corporate Tax Systems: Taxing Business Income Once, Washington, D.C.: US Government Printing Office.

US President's Advisory Panel on Federal Tax Reform (2005), Simple, Fair, and Pro-Growth: Proposals to Fix America's Tax System, Washington, D.C.: US Government Printing Office.

Treaty of Rome (1957), Treaty Establishing the European Economic Community (EEC Treaty), EURLEX.

Treaty of Maastricht (1992), Treaty on European Union, EUR-LEX.

Treaty on European Union (2012), Consolidated version following the Treaty of Lisbon, EUR-LEX.

Van den Tempel, A.J. (1970), Corporation Tax and Individual Income Tax in the European Communities. Brussels: Commission of the European Communities.

Warren, A.C. (2008), The Business Enterprise Income Tax: A First Appraisal, 118 Tax Notes 9, 921928.

Zodrow, G.R. (1991), On the "Traditional” and "New” Views of Dividend Taxation, National Tax Journal 44, 497-509.

Zodrow, G.R. (2006), Capital Mobility and Source-based Taxation of Capital Income in Small Open Economies, 13 International Tax and Public Finance, 269-294.

Zodrow, G.R. (2010), International Taxation and Company Tax Policy in Small Open Economies, chapter 6 in I. Claus, N. Gemmell, M. Harding and D. White, eds., Tax Reform in Open Economies, London: Edward Elgar 


\begin{tabular}{|c|c|c|c|}
\hline & & $\begin{array}{l}\text { Source country corporation tax (CT) on active business income } \\
\text { (profits, capital income, economic rents) }\end{array}$ & $\begin{array}{l}\text { Residence country personal income tax (PT) on passive } \\
\text { income (dividends, interest, capital gains) }\end{array}$ \\
\hline A. Profits & $\begin{array}{l}\text { 1. Classical system } \\
\text { a. dividends } \\
\text { b. capital gains } \\
\text { 2. Full integration system } \\
\text { 3. Dividend relief systems } \\
\text { a. imputation system } \\
\text { b. dividend-deduction system } \\
\text { c. split-rate system } \\
\text { d. ad hoc approaches }\end{array}$ & $\begin{array}{l}\text { Profits taxed in full after deduction of interest } \\
\text { Not taxed at corporate level }\end{array}$ & $\begin{array}{l}\text { Full PT on dividend income net of CT } \\
\text { Reduced PT on realized capital gains } \\
\text { Full PT on corporate profits proportionate to shareholdings } \\
\text { Credit for CT against PT on dividend income grossed up by CT } \\
\text { PT on full dividend income } \\
\text { PT on dividend income net of CT } \\
\text { Lower PT or partial exemption of dividend income }\end{array}$ \\
\hline $\begin{array}{l}\text { B. Capital } \\
\text { income (profits } \\
\text { and interest) }\end{array}$ & $\begin{array}{l}\text { 1. Dual income tax (DIT) } \\
\text { a. dividends } \\
\text { b. interest } \\
\text { c. capital gains } \\
\text { 2. Comprehensive business } \\
\text { income tax (CBIT) } \\
\text { a. dividends } \\
\text { b. interest } \\
\text { c. capital gains }\end{array}$ & $\begin{array}{l}\text { As under A1, but withholding tax on interest } \\
\text { Withholding tax at rate equal to or lower than CT } \\
\text { As under A1, but no deduction for interest }\end{array}$ & $\begin{array}{l}\text { Taxed at PT (=CT) rate with credit for CT or full exemption } \\
\text { Taxed at PT rate with credit for withholding tax } \\
\text { Taxed on excess over basis stepped up by retained corporate } \\
\text { profits net of CT } \\
\text { Exempt } \\
\text { Exempt } \\
\text { Taxed on excess over basis stepped up by retained corporate } \\
\text { profits net of CT }\end{array}$ \\
\hline $\begin{array}{l}\text { C. Economic } \\
\text { rents (above- } \\
\text { normal returns) }\end{array}$ & $\begin{array}{l}\text { 1. Cash-flow or flat tax } \\
\text { a. source-based } \\
\text { (i) dividends } \\
\text { (ii) capital gains } \\
\text { b. destination-based } \\
\text { (i) dividends } \\
\text { (ii) capital gains } \\
\text { 2. Allowance for corporate equity (ACE) } \\
\text { a. dividends } \\
\text { b. capital gains } \\
\text { 3. Rate of return allowance (RRA) } \\
\text { a. dividends } \\
\text { b. capital gains }\end{array}$ & Deduction of normal rate of return from profits net of interest & $\begin{array}{l}\text { Taxed at PT rate } \\
\text { Taxed at (reduced) PT rate } \\
\text { Taxed at PT rate } \\
\text { Taxed at (reduced) PT rate } \\
\text { Taxed at PT rate } \\
\text { Taxed at (reduced) PT rate } \\
\text { Deduction from capital income of normal rate of return (RRA) } \\
\text { Taxed at PT rate after RRA } \\
\text { Taxed at PT rate after RRA }\end{array}$ \\
\hline
\end{tabular}


Table 2. European Union: Corporation Taxes (CTs) and Personal Income Taxes (PTs) on Corporate Source Income in 2016

\begin{tabular}{|c|c|c|c|c|c|c|c|c|c|}
\hline \multirow[t]{2}{*}{ CT-PT system } & \multirow{2}{*}{$\begin{array}{c}\mathrm{CT} \\
\text { rate }^{\mathrm{a}}\end{array}$} & \multirow{2}{*}{$\begin{array}{c}\text { CT } \\
\text { ratio } \\
(2013)\end{array}$} & \multicolumn{3}{|c|}{ PT on dividends } & \multirow{2}{*}{$\begin{array}{l}\text { PT on } \\
\text { capital } \\
\text { gains }^{b}\end{array}$} & \multicolumn{2}{|c|}{ PT Withholding taxes } & \multirow{2}{*}{$\begin{array}{l}\text { Top PT rate } \\
\text { on labor } \\
\text { income }\end{array}$} \\
\hline & & & $\begin{array}{c}\text { Shareholder } \\
\text { level }\end{array}$ & Withholding $^{c}$ & $\mathrm{CT}+\mathrm{PT}^{\mathrm{d}}$ & & Interest & Royalties & \\
\hline \multicolumn{10}{|l|}{ Double taxation } \\
\hline Croatia & 20 & 2.0 & Double tax & 12 & 58 & 12 & $12^{*}$ & 25 & 47.2 \\
\hline Ireland & 12.5 & 2.4 & Double tax & 20 & 45.9 & 33 & 20 & 20 & 51 \\
\hline Lithuania & 15 & 1.4 & Double tax & 15 & 27.7 & 15 & 15 & 15 & 15 \\
\hline Spain & 25 & 2.2 & Double tax & 20 & 59.5 & $19.5-23.5$ & 20 & 20 & 46 \\
\hline \multicolumn{10}{|l|}{ Imputation system } \\
\hline Malta & 35 & 5.6 & $35 / 65$ tax credit & - & 35 & - & - & - & 35 \\
\hline UK & 20 & 2.4 & $1 / 9$ tax credit & - & 52.4 & $18 / 28$ & 20 & 20 & 45 \\
\hline \multicolumn{10}{|l|}{ Dual income tax } \\
\hline Finland & 20 & 2.2 & $15 \%$ exempt & 25.5 & 55.1 & $30 / 33$ & $30 *$ & 30 & 51.6 \\
\hline Sweden & 22 & 2.7 & 30 & 30 & 45.4 & 30 & 30 & - & 57 \\
\hline \multicolumn{10}{|l|}{ Final withholding } \\
\hline Austria & 25 & 2.2 & Exempt & $27.5^{*}$ & 45.6 & $25 *$ & $25^{*}$ & - & 50 \\
\hline Bulgaria & 10 & 1.9 & Exempt & $5^{*}$ & 14.5 & 10 & $8^{*}$ & 10 & 10 \\
\hline Cyprus $^{\mathrm{e}}$ & 12.5 & 6.5 & Exempt & $17^{*}$ & 27.4 & - & $30 *$ & - & 35 \\
\hline Czech Republic & 19 & 3.2 & Exempt & $15^{*}$ & 31.5 & - & $15^{*}$ & - & 22 \\
\hline Denmark & 22 & 2.7 & Exempt & $27 / 42^{*}$ & 54.8 & $27 / 42$ & - & 22 & 55.8 \\
\hline Germany & 30.18 & 2.5 & Exempt & $26.4^{*}$ & 48.6 & 26.4 & $26.4^{*}$ & - & 50.5 \\
\hline Greece & 29 & 1.3 & Exempt & $18^{*}$ & 41.8 & 15 & $23 *$ & $28^{*}$ & 48 \\
\hline Hungary & 20.6 & 1.4 & Exempt & $16^{*}$ & 33.3 & $16^{*}$ & $16^{*}$ & 16 & 16 \\
\hline Latvia & 15 & 1.6 & Exempt & $10^{*}$ & 23.5 & 15 & $10 *$ & - & 23 \\
\hline Luxembourg & 29.22 & 4.9 & $50 \%$ exempt & $15^{*}$ & 34.5 & - & $10^{*}$ & - & 43.6 \\
\hline Poland & 19 & 1.8 & Exempt & $19 *$ & 34.4 & 19 & $19 *$ & 18 & 32 \\
\hline Portugal & 29.5 & 3.4 & Exempt & $28^{*}$ & 49.2 & 28 & $28 *$ & 16.5 & 56.5 \\
\hline Romania & 16 & 2.0 & Exempt & $16^{*}$ & 29.4 & $16^{*}$ & $16^{*}$ & - & 16 \\
\hline Slovak Republic & 22 & 2.9 & Exempt & $19 *$ & 36,8 & $19 / 25$ & $19 *$ & - & 25 \\
\hline Slovenia & 17 & 1.2 & Exempt & $25^{*}$ & 37.7 & 25 & $25 *$ & $25^{*}$ & 50 \\
\hline \multicolumn{10}{|l|}{ Exemption } \\
\hline France $^{f}$ & 38 & 2.7 & $40 \%$ exempt & 21 & 56.7 & 16 & 24 & 33.3 & 50.3 \\
\hline Netherlands & 25 & 2.2 & Exempt & 15 & 25 & - & - & - & 52 \\
\hline \multicolumn{10}{|l|}{ ACE system ${ }^{\mathrm{g}}$} \\
\hline Belgium & 33.99 & 3.1 & Exempt & $25^{*}$ & 50.5 & - & $25^{*}$ & $15^{*}$ & 53.8 \\
\hline Italy (new equity) & 31.4 & 2.5 & Exempt & $26^{*}$ & 49.2 & $26^{*}$ & $26^{*}$ & $15^{*}$ & 48.9 \\
\hline \multicolumn{10}{|l|}{ No $\mathrm{CT}$} \\
\hline Estonia & - & 0.3 & 20 & - & 20 & 20 & 20 & 20 & 20 \\
\hline EU-averages & 23.3 & 2.5 & & & & & & & \\
\hline
\end{tabular}

Source: Author's compilation from Ernst\&Young (2016), Harding (2013), International Bureau for Fiscal Documentation (2016),

PriceWaterhouseCoopers (2016), OECD (2014), and Eurostat (2015). Data are from secondary sources and may not always be accurate or complete. CT ratios are from Eurostat. All rates are in $\% ;^{*}=$ final.

${ }^{a} \mathrm{CT}$ rates include (i) surtaxes in Portugal (1.5\%; 7\%), (ii) surcharges in Belgium (3\%), France (3.3\%; 10.7\%), Germany (5.5\%), and Luxembourg (7\%), (iii) local taxes in Germany (effectively, $14.35 \%$ in Berlin), Hungary (2\%), Luxembourg (6.75\% in Luxembourg City), and Italy (0.9\%; IRAP: 3.3\%). Lower or graduated CT rates apply to lower amounts of profits or to small businesses in Belgium, France, Hungary, Latvia, Lithuania, the Netherlands, Portugal, Spain, and the UK. Minimum taxes are levied in Austria (creditable against the future CT), France, Hungary, Lithuania, Italy, Luxembourg, Romania, and Slovakia.

${ }^{\mathrm{b}}$ PT rates shown are for long-term capital gains. In the Czech Republic, France, Lithuania, and Slovenia, a (vanishing) capital gains tax applies to shares held more than 5 years. Several Member States tax short-term (speculative) gains on shares held less than one year as business income or at higher (effective) PT rates. Various Member States exempt small amounts of capital gains or tax them at a lower rate. Generally, capital gains are not adjusted for inflation. In addition, individual net wealth taxes are levied in France (0.5-1.5\%) and the Netherlands (1.2\%; called presumptive income tax). In Luxembourg, corporations are subject to a $0.5 \%$ net wealth tax.

${ }^{c}$ The final PT withholding tax is optional in Austria, Belgium, Germany, and Portugal.

${ }^{d}$ Calculated as CT + PT(1-CT), in which PT is the final withholding tax or the top rate shown in the last column. Further, the assumption is that profits are distributed in the year in which they are made.

${ }^{\mathrm{e}}$ In Cyprus, the dividend tax of $17 \%$ is called defense contribution, which is also levied at the rate of $30 \%$ on interest and royalties.

${ }^{f}$ France imposes a $3 \%$ additional tax on dividend distributions.

${ }^{\mathrm{g}}$ In Belgium and Italy, taxable profits are reduced by an allowance for corporate equity (ACE) of $1.63 \%$ (2.13\% for SMEs) and $5.4 \%$ (new equity only), respectively. 
Table 3. European Union: Personal Income Tax Treatment of Substantial Holdings and Unquoted Shares

\begin{tabular}{llll}
\hline Country & Type of income & Threshold & Treatment \\
& & & \\
\hline Austria & Capital gains & 1\% ownership & Taxes at 25\% \\
Bulgaria & Capital gains & Unquoted shares & Taxed at $10 \%$ \\
Czech Rep & Capital gains & $5 \%$ ownership or votes & $15 \%$, but exempt after 5 years \\
France & Capital gains & Active shareholders & Taxed as business income \\
Germany & Interest & $10 \%$ ownership & Taxed at progressive rates \\
Greece & Capital gains & $1 \%$ ownership & 60\% taxed as business income \\
Ireland & Capital gains & $0.5 \%$ ownership & Taxes at $15 \%$
\end{tabular}




\begin{tabular}{|c|c|c|c|c|c|c|c|c|c|c|c|c|}
\hline \multirow[t]{2}{*}{$\begin{array}{l}\text { Member } \\
\text { State }\end{array}$} & \multicolumn{3}{|c|}{ Methods and rates (\%) of depreciation ${ }^{a}$} & \multirow[t]{2}{*}{$\begin{array}{l}\text { Inventory } \\
\text { valuation }^{\text {b }}\end{array}$} & \multirow{2}{*}{$\begin{array}{l}\text { Provision for } \\
\text { doubtful } \\
\text { debts }\end{array}$} & \multicolumn{2}{|c|}{$\begin{array}{c}\text { Loss carryover } \\
\text { (years and extent) }\end{array}$} & \multirow[t]{2}{*}{$\begin{array}{l}\text { Group } \\
\text { taxation }\end{array}$} & \multicolumn{3}{|c|}{ Anti-avoidance rules } & \multirow{2}{*}{$\begin{array}{l}\text { Pension/ } \\
\text { investment } \\
\text { funds }\end{array}$} \\
\hline & $\begin{array}{l}\text { Machiner } \\
\text { y }\end{array}$ & Buildings & Intangibles & & & $\begin{array}{l}\text { Forward } \\
\text { (Unl. is Unlimited) }\end{array}$ & Back & & $\begin{array}{l}\text { Debt-equity } \\
\text { ratio }\end{array}$ & $\begin{array}{l}\text { Transfer } \\
\text { pricing rules }^{\mathrm{d}}\end{array}$ & $\begin{array}{l}\text { CFC } \\
\text { legislation }\end{array}$ & \\
\hline Austria & SL-14.3 & SL-2.5 & $\mathrm{SL}-6^{2} / 3$ & LIFO & Allowed & Unl.: $75 \%$ of profits & - & Yes & $3 / 4: 1$ & OECD & - & Exempt \\
\hline Belgium & SL-20/33 & SL-3/5 & SL-20 & LIFO & - & Unlimited & - & No & $5: 1$ & OECD & - & Exempt \\
\hline Bulgaria & SL-30/50 & SL-4 & SL-331/3 & FIFO & - & 5 & Exceptionally & No & $3: 1$ & OECD & - & Exempt \\
\hline Croatia & SL-10 & SL-5 & SL-25 & LIFO & - & 5 & - & No & $4: 1$ & Yes & - & Exempt \\
\hline Cyprus & SL-20 & SL-7 & SL-20 & FIFO & - & 5 & - & Yes & - & Yes & - & Exempt \\
\hline Czech Rep & SL-10 & $\mathrm{SL}-3^{1} / 3$ & SL-331/3 & FIFO & Allowed & 5 & - & No & $4: 1$ & OECD & - & Exempt \\
\hline Denmark & DB-25 & SL-4 & SL-14.3 & FIFO & Allowed & Unl.: $60 \%$ of profits & - & Yes & $4: 1$ & OECD & Yes & Exempt \\
\hline Estonia $^{f}$ & - & - & - & - & - & 7 & - & No & - & Yes & - & Exempt \\
\hline Finland & DB-25 & DB-7 & SL-10 & FIFO & - & 10 & - & No & $25 \%$ of EBITDA & OECD & Yes & Exempt \\
\hline France & DB-10-20 & SL-5 & SL-20 & FIFO & Allowed & Unl.: $50 \%$ of profits & 1:up to $€ 1 \mathrm{ml}$ & Yes & $1.5: 1$ & Yes & Yes & Exempt \\
\hline Germany & DB-20 & SL-4 & $\mathrm{SL}-6^{2} / 3$ & LIFO & Allowed & Unl.: $60 \%$ of profits & 1:up to $€ 1 \mathrm{ml}$ & Yes & $30 \%$ of EBITDA & Yes & Yes & Exempt \\
\hline Greece & SL-10 & SL-4 & SL-10 & LIFO & Allowed & 5 & - & No & $30 \%$ of EBITDA & Yes & Yes & Exempt \\
\hline Hungary & SL-14.5 & SL-2 & SL-50 & FIFO & - & $5: 50 \%$ of profits & - & No & $3: 1$ & Yes & Yes & Exempt \\
\hline Ireland & SL-12.5 & SL-2-4 & SL-7 & FIFO & - & Unlimited & 1 or 3 & Yes & - & OECD & - & Exempt \\
\hline Italy & SL-13.3 & SL-4/8 & SL-50 & LIFO & Allowed & Unl.: $80 \%$ of profits & - & Yes & $30 \%$ of EBITDA & OECD & Yes & Exempt \\
\hline Latvia & DB-20 & DB-10 & SL-100 & FIFO & - & Unlimited & - & No & $4: 1$ & OECD & - & Exempt \\
\hline Lithuania & DB-20 & DB-12.5 & DB- $6^{2} / 3$ & LIFO & - & Unl.: $70 \%$ of profits & - & No & $4: 1$ & OECD & Yes & Exempt \\
\hline Luxembourg & SL-10-20 & SL-4-5 & SL-10-20 & LIFO & Allowed & Unlimited & - & Yes & $85: 15$ & OECD & - & Exempt \\
\hline Malta & SL- $16^{2} / 3$ & SL-2 & SL-8 & FIFO & - & Unlimited & - & Yes & - & No & - & Exempt \\
\hline Netherlands & SL/DB-20 & SL-4 & SL-10 & LIFO & Allowed & 9 & 1 & Yes & - & Yes & - & Exempt \\
\hline Poland & SL-7-20 & SL-1.5-10 & SL-20 & LIFO & - & 5: $50 \%$ of loss & - & Yes & 1:1 & Yes & Yes & Exempt \\
\hline Portugal & SL-12.5 & SL-5 & SL-5 & FIFO & Allowed & $12: 70 \%$ of profits & - & Yes & $30 \%$ of EBITDA & OECD & Yes & Exempt \\
\hline Romania & $S L / D B$ & SL/DB & SL/DB & LIFO & Allowed & 7 & - & No & $3: 1$ & OECD & - & Exempt \\
\hline Slovak Rep & $\mathrm{SL}-16^{2} / 3$ & SL-5 & SL-20 & FIFO & - & 4 & - & No & $25 \%$ of EBITDA & OECD & - & Exempt \\
\hline Slovenia & SL-20 & SL-3 & SL-20 & FIFO & Allowed & Unl.: $50 \%$ of profits & - & No & $4: 1$ & Yes & - & Exempt \\
\hline Spain & DB-25 & SL-3 & SL-10 & FIFO & - & Unlimited & - & Yes & $30 \%$ of EBITDA & Yes & Yes & Exempt \\
\hline Sweden & DB-30 & $S L-2-5$ & DB-30 & FIFO & - & Unlimited & - & No & - & OECD & Yes & Exempt \\
\hline UK & DB-18 & SL-4 & DB-25 & FIFO & - & Unlimited & 1 & Yes & World cap & Yes & Yes & Exempt \\
\hline
\end{tabular}

${ }^{\mathrm{a}} \mathrm{SL}=$ straight line (linear) method; $\mathrm{DB}=$ declining balance method in the first period. Depreciation rates shown represent the most tax efficient possibility; other possibilities, widely allowed, are not shown.

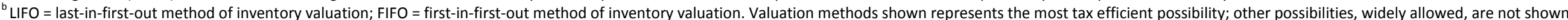

'EBITDA = Earnings before interest, tax and depreciation allowances.

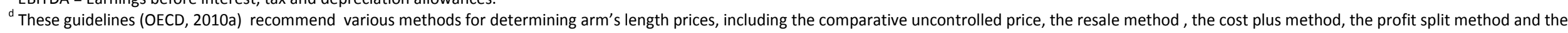
transactional net margin method.

e Under CFC legislation, the possibility of deferring domestic tax on foreign source income is prevented by taxing resident shareholders currently on their proportionate share of some or all of the CFC's income.

${ }^{\mathrm{f}}$ Estonia levies a CT on distributed profits but not on retained profits.

Sources: See Table 2. 
1. Income split All income is systematically separated into either capital income or labor income (also called earned income or personal income). Personal capital income includes interest, dividends, capital gains, imputed returns on capital invested in non-corporate businesses, rents and rental values. Labor income consists of wages and salaries (including the value of the labor services performed by the owner in his or her business), fringe benefits, pension income and social security benefits. Royalties are taxed as labor income or as capital income (if know-how is acquired or capitalized).

2. Tax rates Capital income, individual as well as corporate, is taxed at the proportional CT rate, while labor income is subject to additional, progressive PT rates. To minimize tax arbitrage, the tax rate on labor income applicable to the first income bracket is set at the same level as the proportional CT rate.

3. Costs of earning income Costs of earning income are deductible only against income subject to the capital income tax rate (which is the same as the lowest rate on labor income). This implies that mixed expenses, containing an element of personal consumption, have the same tax value for high- and low-income groups (except for partnerships and proprietorships in whose case the expenses are netted out against gross income before this is split into a capital and a labor income component).

4. Basic allowance for capital income Capital and labor income can be taxed entirely separately, or the two forms of income can be taxed jointly at the CT rate, while gross labor income is subsequently taxed at additional, progressive PT rates. The separate taxation of capital income (which accrues mainly to higherincome groups) without permitting a basic allowance makes it possible to impose flat final source taxes.

5. Offset of negative capital income against labor income Joint taxation at the capital income tax rate permits the offset of negative capital income against positive labor income, which may be desirable since the distinction between labor and capital income tends to get blurred at the level of proprietorships and closely-held companies. If capital and labor income are taxed separately, the same effect can be achieved by permitting a tax credit for negative capital income (calculated at the capital income tax rate) against the tax on labor income.

6. CT-PT integration method The double taxation of distributed profits at the corporate level and the shareholder level can be avoided through a full imputation system. Alternatively but equivalently, double taxation can be avoided by exempting dividend income at the shareholder level. Under either approach, compensatory taxes should guarantee that dividends are not paid out of exempt profits without having borne the CT. Double taxation of retained profits is avoided by writing up the acquisition cost of shares by retained corporate profits net of CT.

7. Withholding taxes The single taxation of capital income can be ensured through withholding or source taxes at the corporate level or at the level of other entities paying interest, royalties or other capital income. In principle, withholding or source rates should be set at the level of the CT rate. Consequently, these rates could represent the final tax liability if capital income is taxed separately from labor income and no basic allowance applies.

8. Unincorporated businesses and closely-held companies The taxable profits of partnerships and proprietorships as well as closely-held corporations, conventionally computed, are split into a capital income component and a labor income component (if the sum of the two components exceeds the first bracket of the labor income tax), and taxed on a current basis. The capital income component is calculated by applying a presumptive return to the value of the gross assets of the business or to equity. Residual profits are considered as labor income. 
Figure 1. European Union: Top Statutory Tax Rates and Corporation Tax Ratios 1995-2013

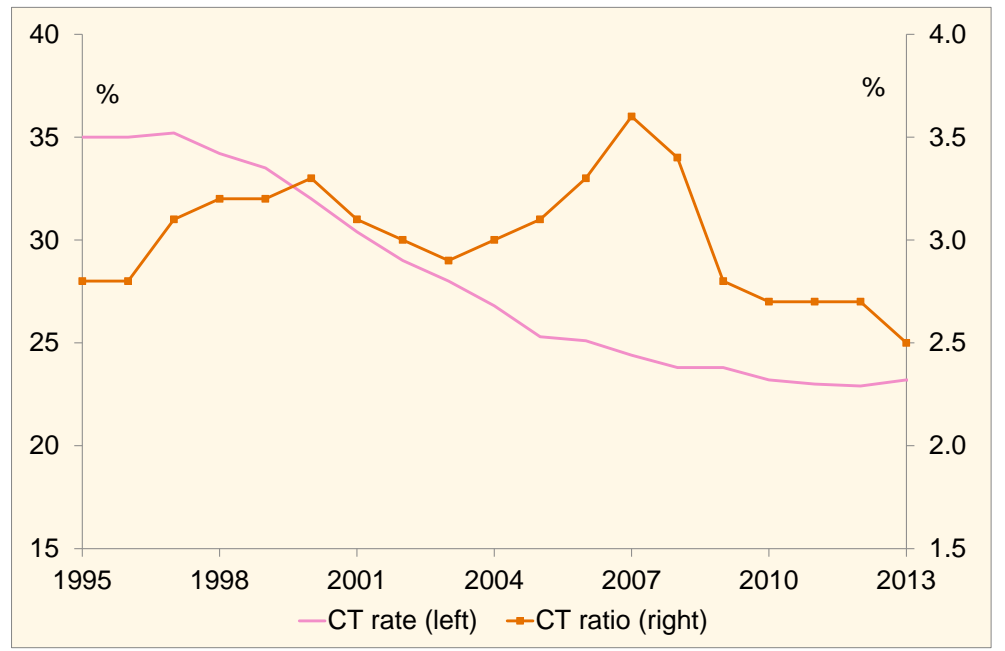

Source: Eurostat (2010, 2014). Calculations are based on simple averages. 